\title{
Lexis
}

Journal in English Lexicology

3 | 2009

Borrowing

\section{Borrowed Borrowings: Nahuatl Loan Words in English}

Jason D. Haugen

\section{(2) OpenEdition}

Journals

\section{Electronic version}

URL: http://journals.openedition.org/lexis/638

DOI: 10.4000/lexis. 638

ISSN: 1951-6215

\section{Publisher}

Université Jean Moulin - Lyon 3

Electronic reference

Jason D. Haugen, « Borrowed Borrowings: Nahuatl Loan Words in English », Lexis [Online], 3| 2009,

Online since 27 July 2009, connection on 30 April 2019. URL : http://journals.openedition.org/

lexis/638; DOl : 10.4000/lexis.638

\section{(@) $\odot \Theta$}

Lexis is licensed under a Creative Commons Attribution-NonCommercial-NoDerivatives 4.0 International License. 


\title{
Borrowed Borrowings: Nahuatl Loan Words in English*
}

\author{
Jason D. Haugen ${ }^{1}$
}

\begin{abstract}
This paper catalogs the words of Nahuatl (aka Mexicano) origin that are attested in the Oxford English Dictionary. These words are cataloged under two classifications: semantic and chronological. Semantically, these words are grouped according to terms pertaining to zoology, botany/horticulture, culinary terms, intoxicants/psychoactives/drugs, mythoreligious terms, cultural items, cultural events, ethnological and linguistic labels, mineralogical terms, and other. Chronologically, words are attested entering the English language in each century since the 1500s, with the earliest borrowing attested in 1555 and the most recent in 1950. Loan words from Nahuatl into English are particularly interesting because they were typically not borrowed due to direct contact with speakers of Nahuatl, but secondarily through contact and trade with speakers of continental and, later, Mexican Spanish, or other European languages.
\end{abstract}

Keywords: loan words - borrowing - Nahuatl - English

\footnotetext{
* This paper has benefited from helpful feedback from Jane Hill as well as three anonymous reviewers. I offer each of them my thanks, and I would like to stress that any remaining inadequacies are the sole responsibility of the author.

${ }^{1}$ Oberlin College, USA, jhaugen@oberlin.edu
} 


\section{Introduction}

This paper presents a catalogue of words of Nahuatl origin that appear in the English language, as indicated by the etymologies recorded in the Oxford English Dictionary (OED).

Nahuatl, also known by the name Mexicano, was the language spoken by the Aztecs as well as other groups indigenous to Central Mexico at the time of the Spanish colonial invasion of Central America in the early $16^{\text {th }}$ century, and varieties of Nahuatl are still spoken by more than 100,000 people in that area to this day. English borrowings from Nahuatl are particularly interesting because they have typically been borrowed from other European languages, primarily Spanish (continental as well as Mexican) but also French or Latin, rather than through direct contact between English and Nahuatl speakers.

Below I present ninety-three words which are given a definitive Nahuatl etymology by the OED. These are presented under two different classifications: (i) a semantic classification based on lexical items occurring in the same (or similar) semantic fields (\$2); and (ii) a chronological classification, based on the time of first attestation in written English, according to the OED (§3).

As we shall see, the loan words that appear in this corpus are in general of the type that would be expected due to contact between colonizing European cultures and the indigenous peoples of the "New World" of Central America. The native terms for previously unknown indigenous concepts such as plants, animals, tools and other cultural items, etc., would typically be borrowed into Spanish by Spanish-speaking colonizers in direct contact with speakers of the indigenous languages (Nahuatl or otherwise), and these terms later passed from Spanish into other European languages (e.g. English or French) through trade among the nations of Europe. In the earliest days this secondary borrowing took place by speakers of British English borrowing from speakers of continental Spanish, but more recent borrowing have obviously more frequently speakers of American English borrowing from speakers of Mexican Spanish.

Nahuatl was, of course, only one of several indigenous languages that had a large impact on colonial Spanish and that, ultimately, led to loan words being borrowed into English (and other languages). Zamorra (1982), for example, discusses the relatively (and disproportionately) large linguistic influence of Taino on Spanish throughout the Western Hemisphere, which was a direct result of very early contact of speakers of those two languages. Many Spanish borrowings from Nahuatl and Quechua, on the other hand, came into the language later and have been limited by an "equatorial isogloss", where loans from Nahuatl are generally used north of the equator and loans from Quechua are preferred in the south (p. 162). Loan words that have passed into Latin American Spanish from other indigenous languages tend to be even much more sporadic and localized.

Likewise, English is not the only recipient of Nahuatl loan words borrowed through an intermediary language like Spanish. Because of the global nature of Spanish colonial trade, after the fall of Mexico many Nahuatl loan words were exported back to Europe (along with Aztec goods), and even as far afield as the Philippines (Leon-Portilla 1960, cited by Lozano 1981). In addition, since speakers of Nahuatl were long used as "translators" for the Spanish both during the colonization of Mexico and what eventually became the modern-day U.S. Southwest, Nahuatl became a kind of lingua franca and many of its words became loans into other indigenous languages as well, sometimes via Spanish but also in some cases directly (Bright 1979, 2000; Miller 1990).

For a more comprehensive documentation of American (and Mexican) indigenous loan words in (primarily American) English see Cutler (1994) and Carney (1997). A classic early study of Nahuatl loan words in American English was presented by Watson (1938), who gives a particularly detailed catalogue of botanical and culinary words of Nahuatl origin on 
the US southwestern frontier. Below my focus will be limited to the current documentation of English loan words that are given a clear Nahuatl etymology in the OED (but see Appendix G).

This paper is organized as follows. Section 2 organizes the ninety-three Nahuatl loan words into categories based on semantic fields. Section 3 then gives a chronological classification of the loan words, grouping them according to the century of their first attestation. If the OED specifically notes an intermediary language then this is also noted here. Section 4 then presents some general discussion of the results of my survey. It should be pointed out that only the words given a clear Nahuatl etymology by the OED are included in sections 2-4. Appendices A and B present the OED's key definitions and etymological notes, respectively, for these words.

The primary lists given below are not completely satisfactory for two reasons. First, they include some words which are obviously not in frequent use in any variety of spoken English (at least not in everyday, non-specialized discourse), and secondly, these lists are incomplete because they do not include other possible Nahuatl words for Nahuatl concepts (such as deity names) or place names that are used by English speakers, even if only in typically academic contexts, but which are not recorded (and therefore not "canonized") by the OED. (See Appendix G for further Nahuatl loan words noted by Watson 1938, which are either not noted as Nahuatl loans or not recorded at all in the OED).

The OED also includes some English borrowings that may or may not involve Nahuatl etymologies. I include these in the next three Appendices. Appendix $\mathrm{C}$ includes words that the OED says might involve a Nahuatl origin, but for which I find some specific reason to doubt a connection to Nahuatl. Appendix D presents the OED's examples of words that have at one time spuriously been connected to Nahuatl, but which are now definitely known to not be connected or are cast into serious doubt. Appendix E includes a range of indigenous loan words, identified as "Mexican" by the OED, which given their similarity in form to other words of definitive Nahuatl origin I think might also plausibly be of Nahuatl origin, and which may be confirmed (or discounted) as such in future research. Appendix F lists the OED citations for each of the lexical entries in all of the earlier appendices, as some entries have been updated in the online database since the publication of the print version of the OED's Second Edition in 1989. As noted above, Appendix G includes the list of loan words in American English identified by Watson (1938) as being from Nahuatl. This list includes some terms that are not marked specifically as being from Nahuatl by the OED, as well as some regionalisms (primarily from Texas and Arizona) that are not recorded in the OED at all. I identify these and include Watson's proposed definition and etymology for each.

Before presenting the word lists I would like to make a quick remark on the method that I employed in this survey. To collect the information on Nahuatl borrowings contained in the OED I ran an advanced search in the OED's "etymologies" field for the search terms Nahuatl, Aztec, and Mexican ( Mexicano). ${ }^{2}$ The lack of a consistent reference to the name of the indigenous language made the compilation of the overall list more difficult than was necessary, and would be problematic for someone searching who did not use each of the three different language names. There was only a slight overlap in the three resulting lists, and it was clear in most cases that the OED intended "Mexican" to be interpreted as "Nahuatl". In the following classifications I only include the main entries for those lexical items which appear multiple times: e.g. chile/chilly but not the obvious compound forms chile ancho, chile poblano, etc., or derived forms such as those from Mexico and Mexican like Mexicanize, Mex, Tex-Mex, or forms like pellotine, which is derived from peyote (both chemically, in the literal sense of the chemical pellotine being derived from the peyote plant, as well as etymologically), and pulqueria, the name for a shop or bar that sells pulque, etc.

\footnotetext{
${ }^{2}$ My compiled data were last cross-checked on September 10, 2008.
} 


\section{Semantic Classification}

I have grouped the Nahuatl loan words into the following semantic classifications: zoological terms, including the names of animals; botanical/horticultural terms, including the names of plants and man-made agricultural features; culinary terms, including foods and plants cultivated and/or prepared for human consumption, not including medicinal or intoxicating substances; intoxicants, including alcoholic beverages, psychoactive plants and other drugs; mytho-religious terms, including the name of a deity and terms for religious locations; cultural items, including tools and products of human labor; cultural events, including the name for the Mesoamerican ballgame (tlachtli); ethnological and linguistic group labels; a single mineralogical term; and one term which is simply categorized here as other.

Table 1 summarizes these categories and shows the number of terms represented in each category. Further explication and a full listing of the terms in each category follow in subsequent sub-sections.

\begin{tabular}{|ll|}
\hline Category & \# of Terms \\
\hline Zoological & 11 \\
\hline Botanical/Horticultural & 15 \\
\hline Culinary & 21 \\
\hline Intoxicants/Psychoactives/Drugs & 10 \\
\hline Mytho-Religious & 4 \\
\hline Cultural Items & 11 \\
\hline Cultural Events & 1 \\
\hline Ethnological/Linguistic Labels & 18 \\
\hline Mineralogical & 1 \\
\hline Other & 1 \\
\hline Total & 93 \\
\hline
\end{tabular}

Table 1: Semantic categories and the number of terms found in each

\subsection{Zoological Terms}

The zoological terms include the names of mammals (cacomistle, conepatl, coyote, mazame, ocelot), reptiles (axolotl, teguexin), insects (pinacate), and birds (quetzal, zopilote). The complete list of Nahuatl-derived zoological terms is given in Table 2. In each of the tables below I include the Nahuatl-derived term and its first attestation in English. Definitions are given in Appendix A, and the etymology provided by the OED is given in Appendix B.

\begin{tabular}{|ll|}
\hline axolotl & 1786 \\
\hline cacomistle & 1869 \\
\hline conepatl & 1774 \\
\hline colin & 1678 \\
\hline coyote & 1824 \\
\hline mazame & 1791 \\
\hline ocelot & 1774 \\
\hline pinacate & 1895 \\
\hline
\end{tabular}




\begin{tabular}{|ll|}
\hline quetzal & 1800 \\
\hline teguexin & 1879 \\
\hline zopilote & 1787 \\
\hline
\end{tabular}

Table 2. Zoological terms derived from Nahuatl

One comment that I would like to make here, which also applies to each of the sub-sections below, is that it would be a very interesting project to trace the history of the incorporation into English of each term in each of the semantic fields that I have identified. However, this kind of in-depth lexical stratigraphy goes beyond the scope of the present paper.

One remark regarding these zoological terms specifically, however, is that it is interesting that some of the more common everyday English words were not borrowed until relatively recently, e.g. coyote (1824) and pinacate (1895). Some of the earliest terms, such as colin (1678) and mazame (1791) seem not to have "caught on" nearly as well. With respect to the zoological terms this is no doubt related to the fact that the physical distribution of certain animals may be limited to the more southerly geographic zones and hence these have not necessitated frequent reference by speakers of English (unlike, say, the ubiquitous coyote). However, a more thorough stratigraphic project may well find more interesting socio-historic rationales for the adoption (or not) of particular loan words, whether of Nahuatl or other origins.

\subsection{Botanical and Horticultural Terms}

Nahuatl-derived botanical terms include the names of trees (ahuehuete, hule, mesquite, $\dagger$ mizquitl, ocote, oyamel); shrubs (guayule, Tecoma); plants (melt $n .^{2}$, quamoclit, tule); and grasses (sacate/zacate, teosinte). Horticultural terms include two words describing particular ways to cultivate the environment to grow plants for human use: chinampa and milpa.

This list is summarized in Table 3:

\begin{tabular}{|ll|}
\hline ahuehuete & 1828 \\
\hline chinampa & 1832 \\
\hline guayule & 1906 \\
\hline hule & 1846 \\
\hline melt, $n .^{2}$ & 1605 \\
\hline mesquite $^{2}$ & 1759 \\
\hline milpa & 1648 \\
\hline †mizquitl (obsolete) & 1753 \\
\hline ocote & 1787 \\
\hline oyamel & 1871 \\
\hline quamoclit & 1633 \\
\hline sacate/zacate & 1848 \\
\hline Tecoma & 1846 \\
\hline teosinte & 1877 \\
\hline tule & 1837 \\
\hline
\end{tabular}

Table 3. Botanical and Horticultural terms derived from Nahuatl

Once again we see a large range of dates for the different initial times of incorporation for each of the various terms. It is interesting to note that the earliest terms were borrowed into English in 1605 and 1648, which is around 80 to 120 years after the first contacts of the 
Spanish with the Aztecs (Tenochtitlan fell to Cortez in 1521). One observation is that the term mizquitl, dated to 1753, was apparently made obsolete (through morphological modification to a more Spanish-sounding form) very early on, since mesquite is attested in English as early as 1759 .

The majority of these terms, however, were borrowed into English from the very late $18^{\text {th }}$ century and later, which reflects the history of the expanding United States western frontier during that time period. Watson (1938) is a particularly invaluable resource on the record of Nahuatl-derived botanical borrowings in the US Southwest (especially in Arizona and Texas) in this historical period, and he includes a number of words for American English that are not recorded by the OED; see Appendix G for examples.

\subsection{Culinary Terms}

In the category of culinary terms I include fruits, vegetables and other edible plants that are typically consumed by humans for food, as well as the names for preparations (cooked or smoked) of foods including fruits and vegetables. I do not include here preparations or plants that are used as intoxicants or for medicinal purposes.

The OED attests several names for fruits, vegetables and edible plants (avocado, camote, chayote, chili/chilly, jalapeño, jicama, jicara, nopal, and tomato), as well as to the names for cooked (or otherwise prepared) foods (atole, chipotle, chocolate, guacamole, mole $\left(n{ }^{7}\right)$, pinole, posole, and pupusa). Edible and preparable seeds include cacao and the later corrupted form cocoa, both of which can refer to the seeds themselves as well as the concoction(s) made from those seeds, as well as chia. A final term is chicle, which refers to the plant-derived gum-like substance which serves as the source for chewing gum.

These terms are summarized in Table 4.

\begin{tabular}{|c|c|}
\hline atole & 1716 \\
\hline avocado & 1697 \\
\hline cacao & 1555 \\
\hline camote & 1842 \\
\hline chayote & 1884 \\
\hline chia & 1832 \\
\hline chicle & 1889 \\
\hline chili/chilly & 1662 \\
\hline chipotle & 1950 \\
\hline chocolate & 1604 \\
\hline cocoa & 1672 \\
\hline guacamole & 1920 \\
\hline jalapeño & 1949 \\
\hline jicama & 1604 \\
\hline jicara & 1859 \\
\hline mole, $n .^{7}$ & 1891 \\
\hline nopal & 1578 \\
\hline pinole & 1648 \\
\hline posole & 1699 \\
\hline pupusa & 1948 \\
\hline tomato & 1604 \\
\hline
\end{tabular}

Table 4. Culinary terms derived from Nahuatl 
Culinary items is the largest category of Nahuatl borrowings since it contains the most lexical items. It is also the one which has the greatest spread of dates of first attestation, containing the earliest attested borrowing (cacao, 1555) as well as the most recent (pupusa, jalapeño, chipotle, from 1948, 1949, and 1950, respectively). It is quite clear that food is a major domain for cultural (and hence, linguistic) borrowing, and it would not be surprising if more Nahuatl-derived borrowings will be incorporated into English (and other languages) from Spanish in the future, as Mexican and other Latin American cuisines spread in popularity from the US Southwest to broader areas of the United States and, indeed, the world.

\subsection{Intoxicants, psychoactive plants, and other drug terms}

The terms in this category include the names of plants with psychoactive properties (ololiuqui, peyote, teonanacatl, toloache); alcoholic beverages, which are derived from the processing of plants (octli, pulque, sotol, tepache); one term which is used for both of the aforementioned functions, albeit with reference to the use of (or the product derived from the use of) different plants (mescal); and the name of a drug that is derived from the resin contained within the tubers of a particular plant (jalap).

These lexical items are summarized in Table 5:

\begin{tabular}{|ll|}
\hline jalap & 1675 \\
\hline mescal & 1709 \\
\hline octli & 1787 \\
\hline ololiuqui & 1894 \\
\hline peyote & 1849 \\
\hline pulque & 1572 \\
\hline sotol & 1881 \\
\hline teonanacatl & 1875 \\
\hline tepache & 1926 \\
\hline toloache & 1894 \\
\hline
\end{tabular}

Table 5. Terms for intoxicants, psychoactive plants, and other drugs derived from Nahuatl

The OED also lists the name of another plant with psychoactive properties, marijuana (1894), as an additional possible word of Nahuatl origin. The OED attributes the word marijuana to Mexican Spanish marihuana, which is listed as "of uncertain origin" but possibly relatable to the Nahuatl word mallihuan 'prisoner'. With no other evidence presented aside from the possibly accidental phonological similarity between marihuana and mallihuan, I am not at all convinced by this proposed etymology, and thus have placed marijuana in Appendix $\mathrm{C}$ as an English borrowing improbably attributed to Nahuatl. See that Appendix for further discussion.

\subsection{Mytho-Religious terms}

The mytho-religious terms in the corpus include Quetzalcoatl, the name of a specific god in Aztec religious belief, and the concept nagual, which is defined by the OED as "a guardian spirit in animal form, believed to accompany and guide an individual through life; an animal form believed to be assumed by a human through magical or supernatural means". I also include in this category two terms for locations relevant to the practicing of religion: teocalli and teopan.

These terms are summarized in Table 6: 


\begin{tabular}{|ll|}
\hline nagual & 1822 \\
\hline Quetzalcoatl & 1578 \\
\hline teocalli & 1613 \\
\hline teopan & 1891 \\
\hline
\end{tabular}

Table 6. Mytho-religious terms derived from Nahuatl

This is one section for which the OED is quite impoverished compared to the set of words that could be considered as possible borrowings from Nahuatl. The anthropological, archaeological, and historical records are replete with the indigenous names for a vast cosmology, including the names of deities (many more than simply Quetzalcoatl) and other mythological beings, rituals, locations, calendrical terms, and more. Although perhaps not in everyday use among most speakers of English, the inclusion of such terms from the specialized literature would greatly amplify the number of extant Nahuatl borrowings used in the English language.

\subsection{Terms for cultural items}

I include under the broad label "cultural items" such things as tools (atlatl, mecate, metate, molcajete, petaca); products of human labor, such as shelter (jacal), clothing (tilma), or sleeping mats (petate); and natural things that are used by humans for functions other than those listed above (copal, istle, tacamahac).

These borrowings are summarized in Table 7:

\begin{tabular}{|ll|}
\hline atlatl & 1871 \\
\hline copal & 1577 \\
\hline istle & 1883 \\
\hline jacal & 1838 \\
\hline mecate & 1849 \\
\hline metate & 1625 \\
\hline molcajete & 1906 \\
\hline petaca & 1648 \\
\hline petate & 1843 \\
\hline tacamahac & 1577 \\
\hline tilma & 1851 \\
\hline
\end{tabular}

Table 7. Terms for cultural items

One interesting thing to note is that, although this is a relatively modest list, words are represented from each of the relevant centuries with the exception of the $18^{\text {th }}$ century (i.e. the 1700s). This may reflect the lag time between the earliest adoption and trade of Aztec goods in Europe (in the $16^{\text {th }}$ and $17^{\text {th }}$ centuries) and the later contact and subsequent borrowing amongst English-speaking Americans and Spanish speakers on the western US frontiers since the $19^{\text {th }}$ century.

\subsection{Terms for cultural events}

There is one term that I classify uniquely as a "cultural event" - tlachtli, which as a label refers to the ceremonial ballgame of the Aztecs. This term is shown in Table 8: 


tlachtli 1875

Table 8. A term for a cultural event

Once again, it would be possible to include the indigenous names for other events or rituals of the Aztec world (e.g. Toxcatl) as further Nahuatl borrowings into English. The OED seems to be silent on which criteria are used to exclude those but allow tlachtli.

\subsection{Ethnological labels and/or language names}

Not surprisingly, the names of many ethnic groups and languages (or language groups) indigenous to Mexico have Nahuatl origins, and some of these have been borrowed into English. As in many cases, such names can often be used either for a group of people or for the language(s) they speak. The list of these Nahuatl-derived terms is given in Table 9:

\begin{tabular}{|ll|}
\hline Chicano & 1947 \\
\hline Mazatec & 1892 \\
\hline Mexican & 1578 \\
\hline Mixe & $\mathrm{a} 1616$ \\
\hline Mixteca & 1787 \\
\hline Mixteco & 1911 \\
\hline Nahua & 1875 \\
\hline Nahuatl & 1858 \\
\hline Nahuatlaca & 1775 \\
\hline Nahuatlan & 1897 \\
\hline Oaxacan & 1897 \\
\hline Olmec & 1852 \\
\hline Olmeca & 1787 \\
\hline Otomi & 1782 \\
\hline Tlapanec & 1875 \\
\hline Toltec & 1787 \\
\hline Totonac & 1787 \\
\hline Zapotec & 1797 \\
\hline
\end{tabular}

Table 9. Ethnographic labels and language names

Given the specifically political nature of many acts of what we may term ethnonymization, where outsider labels (exonyms) for a particular group are often imposed upon that group, the in-depth study of the adoption of these particular Nahuatl-based ethnic labels, to the exclusion of other possible labels and/or endonyms, would be very interesting.

\subsection{A Mineralogical Term}

The OED lists a single term related to mineralogy: chalchuite, which refers to a Mexican variety of turquoise.

\begin{tabular}{|l|}
\hline chalchuite \\
\hline
\end{tabular}

Table 10. A mineralogical term 
There surely must be other mineralogical features unique to Mesoamerica that had Nahuatl names. Perhaps if such terms have ever been borrowed into English, e.g. among geologists, mineralogists, and other earth science specialists, their use is sufficiently specialized as to have been excluded from the OED.

\subsection{Other}

There is one final term that I leave unclassified, since it is derived from a proper noun: i.e. Montezuma. The OED only gives examples of Montezuma as a modifier, as in compounds such as Montezuma quail and in Montezuma's revenge. Montezuma is derived from the Aztec ruler at the time of Spanish contact, Montezuma II (1466-1520, according to the OED). The earliest English citation given in the OED for Montezuma is in the term Montezuma quail from 1917, although the Latinate variant, Cyrtonyx montezumae, is cited as early as 1830 .

This concludes our presentation of the Nahuatl loan words in their semantic classification. We now turn to the chronological classification.

\section{Chronological Classification}

My chronological classification groups the Nahuatl loan words according to which century they were borrowed in, as evidenced by the earliest recorded appearance of each term in English writing. The earliest attestation of a Nahuatl loan word is 1555 for cacao, and the most recent is 1950 for chipotle. As the following tables reveal, there were seven terms borrowed in the $16^{\text {th }}$ century (Table 11 ); seventeen in the $17^{\text {th }}$ century (Table 12 ); eighteen in the $18^{\text {th }}$ century (Table 13); forty-one in the $19^{\text {th }}$ century (Table 14); and ten in the $20^{\text {th }}$ century. Each of these tables includes the date of the first attestation of each entry, as well as the intermediary language it was borrowed through, if so noted by the OED.

\begin{tabular}{|lll|}
\hline$\underline{\text { Date }}$ & Entry & Intermediary Language \\
\hline 1555 & cacao, $n$. & Spanish \\
\hline 1572 & pulque, $n$. & Central American Spanish \\
\hline 1577 & copal, $n$. & Spanish, French \\
\hline 1577 & tacamahac, $n$. & Spanish \\
\hline 1578 & Mexican, $n$. and adj. & Spanish \\
\hline 1578 & nopal, $n$. & Spanish \\
\hline 1578 & Quetzalcoatl, $n$. & Spanish \\
\hline
\end{tabular}

Table 11. 16 $^{\text {th }}$ Century Nahuatl Borrowings

\begin{tabular}{|l|ll|}
\hline 1604 & chocolate & French, Spanish \\
\hline 1604 & jicama, $n$. & Mexican Spanish \\
\hline 1604 & tomato, $n$. & French, and/or Spanish and Portuguese \\
\hline 1605 & melt, $n .{ }^{2}$ & Middle French \\
\hline 1613 & teocalli, $n$. & - \\
\hline$a 1616$ & Mixe, $n$. and $a d j$. & Mexican Spanish \\
\hline 1625 & metate, $n$. & Mexican Spanish \\
\hline 1633 & quamoclit, $n$. & post-classical Latin \\
\hline 1648 & milpa, $n$. & Mexican Spanish \\
\hline
\end{tabular}




\begin{tabular}{|l|ll|}
\hline 1648 & petaca, $n$. & Spanish \\
\hline 1648 & pinole, $n$. & Spanish \\
\hline 1662 & chilli, chilly & Spanish \\
\hline 1672 & cocoa, $n$. & Spanish \\
\hline 1675 & jalap, $n$. & French, ad. Spanish \\
\hline 1678 & colin, $n$. & - \\
\hline 1697 & avocado, $n$. & Spanish \\
\hline 1699 & posole, $n$. & Mexican Spanish \\
\hline
\end{tabular}

Table $12.17^{\text {th }}$ Century Nahuatl Borrowings

\begin{tabular}{|lll|}
\hline 1709 & mescal, $n$. & American Spanish \\
\hline 1716 & atole & American Spanish \\
\hline 1753 & mizquitl, $n$. & Mexican Spanish \\
\hline 1759 & mesquite, $n$. & Mexican Spanish \\
\hline 1774 & conepatl, $n$. & - \\
\hline 1774 & ocelot, $n$. & French (< Spanish) \\
\hline 1775 & Nahuatlaca, $n$. and $a d j$. & - \\
\hline 1782 & Otomi, $n$. and $a d j$. & Mexican Spanish \\
\hline 1786 & axolotl, $n$. & - \\
\hline 1787 & Mixteca, $n$. and $a d j$. & Spanish \\
\hline 1787 & ocote, $n$. & Mexian/Central American Spanish \\
\hline 1787 & octli, $n$. & - \\
\hline 1787 & Olmeca, $n$. & - \\
\hline 1787 & Toltec, $n$. and $a$. & Spanish \\
\hline 1787 & Totonac & Spanish \\
\hline 1787 & zopilote, $n$. & Spanish \\
\hline 1791 & mazame, $n$. & French \\
\hline 1797 & Zapotec, $n$. and $a$. & Spanish \\
\hline
\end{tabular}

Table 13. $18^{\text {th }}$ Century Nahuatl Borrowings

\begin{tabular}{|lll|}
\hline 1800 & quetzal, $n$. & Mexican Spanish \\
\hline 1822 & nagual, $n$. & Mexican Spanish \\
\hline 1824 & coyote, $n$. & Mexican Spanish \\
\hline 1828 & ahuehuete, $n$. & Mexican Spanish \\
\hline 1832 & chia, $n^{2}$ & Mexican Spanish \\
\hline 1832 & chinampa, $n$. & - \\
\hline 1837 & tule, $n$. & Spanish \\
\hline 1838 & jacal & Mexican Spanish \\
\hline 1842 & camote & Mexican Spanish \\
\hline 1843 & chalchuite, $n$. & - \\
\hline 1843 & petate, $n$. & Spanish \\
\hline 1846 & hule & Mexican Spanish \\
\hline 1846 & Tecoma, $n$. & - \\
\hline 1848 & sacate, zacate & Mexican Spanish \\
\hline 1849 & mecate, $n$. & Mexican Spanish \\
\hline 1849 & peyote, $n$. & Spanish \\
\hline 1851 & tilma & Mexican Spanish \\
\hline
\end{tabular}




\begin{tabular}{|lll|}
\hline 1852 & Olmec, $n$. and adj. & - \\
\hline 1858 & Nahuatl, adj. and $n$. & Spanish \\
\hline 1859 & jicara & American Spanish \\
\hline 1869 & cacomistle & American Spanish \\
\hline 1871 & atlatl & - \\
\hline 1871 & oyamel, $n$. & Mexican Spanish \\
\hline 1875 & Nahua, $n$. and $a d j$. & - \\
\hline 1875 & teonanacatl & - \\
\hline 1875 & tlachtli & - \\
\hline 1875 & Tlapanec, $n$. (and $a$. ) & Spanish \\
\hline 1877 & teosinte, $n$. & French \\
\hline 1879 & teguexin & - \\
\hline 1881 & sotol, $n$. & American Spanish \\
\hline 1883 & istle, $n$. & - \\
\hline 1884 & chayote & Spanish \\
\hline 1889 & chicle, $n$. & American Spanish \\
\hline 1891 & mole, $n$. & Mexican Spanish \\
\hline 1891 & teopan, $n$. & - \\
\hline 1892 & Mazatec, adj. and $n$. & Spanish \\
\hline 1894 & ololiuqui, $n$. & - \\
\hline 1894 & toloache & Mexican Spanish \\
\hline 1895 & pinacate, $n$. & Mexican Spanish \\
\hline 1897 & Nahuatlan, $n$. and $a d j$. & - \\
\hline 1897 & Oaxacan, $n$. and $a d j$. & Spanish \\
\hline & &
\end{tabular}

Table 14. $19^{\text {th }}$ Century Nahuatl Borrowings

\begin{tabular}{|lll|}
\hline 1906 & guayule & American Spanish \\
\hline 1906 & molcajete, $n$. & Mexican Spanish \\
\hline 1911 & Mixteco, $n$. and $a d j$. & Spanish \\
\hline 1917 & Montezuma, $n$. & - \\
\hline 1920 & guacamole & American Spanish \\
\hline 1926 & tepache & Mexican Spanish \\
\hline 1947 & Chicano, $n$. and $a d j$. & Mexican Spanish \\
\hline 1948 & pupusa, $n$. & American Spanish (El Salvador) \\
\hline 1949 & jalapeño, $n$. & Mexican Spanish \\
\hline 1950 & chipotle, $n$. & Mexican Spanish \\
\hline
\end{tabular}

Table 15. 20 ${ }^{\text {th }}$ Century Nahuatl Borrowings

The chronological classification of the Nahuatl loan words is of interest because of the clear historical need for English speakers to borrow different Nahuatl words from various sources at different times. For example, borrowings from continental Spanish into British English prevailed in the first centuries after contact with the indigenous peoples of the Western Hemisphere, but borrowing from Mexican Spanish into American English has been the norm more recently. The reason for this is that the introduction of the Nahuatl terms in the first century or two resulted from trade amongst various European nations with Spain after Spain had brought Aztec goods back to Europe. It was only later, as English-speaking Americans continued to spread westward and began to encounter Spanish-speaking peoples in the "New 
World", first with New Spain and then, after 1821, Mexico, that Nahuatl-derived terms began to be borrowed directly into American English. This is not necessarily reflected in the etymologies listed in the OED, however, other than listing most non-Spanish sources of Nahuatl loans in the earliest periods (with, for example, only one non-Spanish borrowing, teosinte, listed since the end of the $18^{\text {th }}$ century).

A careful history of each term and its path into English would be an extremely interesting project that would minimally require tracing each of the quotations used in the OED, but this still remains to be done.

\section{Discussion}

There are several notes of linguistic interest that can be made about Nahuatl loan words, particularly in regard to the phonological and morphological adaptations that have occurred in the borrowing process.

The most striking phonological adaptation is the typical replacement of two non-Spanish phonemes found in Nahuatl: $/ t l /$ and $/ t z /$. The former is maintained word-initially in two borrowings (tlachtli and Tlapanec), but is usually replaced with -te word-finally (see discussion below), while the latter is replaced with ch- word-initially (e.g. Sp. chicle $<$ Nah. tzictli); word-internally, -tz- has been retained in some forms (e.g. quetzal) while being replaced with - ch- in others (e.g. toloache, derived from the compounded form of toloa 'to bow the head' + tzin 'reverential').

There are at least two noteworthy morphological adaptations of Nahuatl grammar attested in these borrowings. The first was the blurring of Nahuatl derived forms, such as compounds, into new simple Spanish roots. These include such forms as chipotle $(<\mathrm{Nah}$. chil- 'chili' + poctli 'smoke'); ${ }^{3}$ conepatl $(<\mathrm{Nah}$. cone- 'child' + epatl 'fox'); and teosinte $(<\mathrm{Nah}$. teotl 'god' + cintli/centli 'dry ear or cob of maize'). At least one Spanish form maintains a relatively clear Nahuatl-derived compound, whereas it is probably more like a root for most English speakers: guacamole ( $<\mathrm{Sp}$. ahuacate 'avocado' + mole 'sauce' < Nah. ahuacatl 'avocado' + molli 'sauce'). It is interesting to note that the Anglicization of this word as something like [gwa-k[- mo-li] accidentally brings the pronunciation of the second compound element more in line with the Nahuatl original than is the case for this term in Spanish. The same is true for English chili, which is (accidentally) much closer to the original Nahuatl chilli than is the Spanish chile. Most English speakers sensitive to the Spanish origin of the Nahuatl-derived word chili prefer and use the Spanish form. In this situation, then, the issue of "authenticity" arises, and it would be interesting to see how this might play out among different speakers (or groups of speakers) if the Nahuatl origin were more popularly known (i.e. whether speakers now preferring chile would revert to the more indigenous-sounding, and thus potentially more "authentic", pronunciation, even if this so happens to be nearly identical to the Anglicization, chili, of the Nahuatl word).

The second morphological adaptation involved the reanalysis, or perhaps more accurately stated as non-analysis, of certain aspects of Nahuatl morphological structure. The most obvious example of this is found in the case of the so-called "absolutive" suffix $-t l$, which in Nahuatl marks the end of non-possessed nominals and appears in complementary distribution with pronominal possessor prefixes. Since the "citation form" of various nouns are typically not given in the context of being possessed, many Nahuatl nouns borrowed into Spanish took this form. Since $/ \mathrm{tl} /$ was not a phoneme of Spanish the phonological adaptation of word final -

\footnotetext{
${ }^{3}$ The OED states that the form chipotle dates from "1976 or earlier", but that this English borrowing is attested as chilpocle or chilpotle in "1953 or earlier". Note the phonological simplification that obscures the clear nature of the original compound as being derived from chil- 'chili'.
} 
$t l$ into (usually) -te went along with the reanalysis of the morphologically complex form into a simplex root form. For example, the Spanish etymon of English tomato, tomate, derives from the Nahuatl root toma, which in its non-possessed form would have been tomatl. When marked with a possessor prefix, however, the $-t l$ suffix would not have appeared. The replacement of $-t l$ with $-t e$ is quite characteristic (viz. chocolate, coyote, mecate, mesquite, metate, and many others), although Spanish -te also replaced the Nahuatl ending -tli in some forms (e.g. camote, chayote, teosinte). Only a few English borrowings, derived from written Spanish sources giving the original Nahuatl words, survive with the -tl endings: atlatl, conepatl, the obsolete †mesquitl (which was quickly replaced in the spoken language by the Spanish-derived mesquite), Nahuatl, Quetzalcoatl, and teonanacatl.

\section{Conclusion}

In sum, the English language contains a large number of Nahuatl loan words which entered the language through a process of secondary borrowing. I have documented the OED's attestation of these words along two separate classifications (semantically and chronologically). In the Appendices I discuss some words which will have to be either confirmed or discounted as Nahuatl loans in future research, and I also include comprehensive coverage of an earlier survey by Watson (1938), who documented additional Nahuatl loan words in certain varieties of American English that have not been included in the OED.

This primarily descriptive study leaves several important lines of investigation open for future work. First and foremost would be a more detailed study of the actual use (spoken or written) of individual words cited in this collection. It would be quite informative to investigate more thoroughly how individual Nahuatl words got incorporated into different languages (e.g. first Spanish, and then English and other European languages) through different borrowing contexts, and then to see how they may or may not have been maintained in spoken (and/or written) language. I have an impression that the vast majority of these words are not in general circulation among most speakers of English at this point in time, and the ones which are used the most frequently are probably no longer recognized as borrowings, either from Spanish or from Nahuatl (e.g. chocolate, coyote, tomato, etc.). Other terms circulate only in specialized discourses (e.g. Quetzalcoatl, teocalli, etc.). Future questions that should be addressed include: which of these vocabulary items are actually known, and to what group(s) of speakers? Which words are actually used, and by whom, where, when, and why?

An additional line of investigation would pertain to the historiography of the Oxford English Dictionary itself, and the processes that led to the "canonization" of this particular set of terms to the exclusion of others. One contribution that I hope that this article will make is to encourage a more in-depth look at the pioneering work of Watson (1938), to see if some subset of his proposals for Nahuatl borrowings into regional variants of American English can be confirmed and possibly incorporated into future editions of the OED.

To conclude, the history of the incorporation of these Nahuatl words into the English language is particularly rich, given the complexity of the historical circumstances involving differing geographical, temporal and sociopolitical contexts of colonialism, trade, and other inter-cultural contacts that led to centuries of borrowing a large number of secondary loan words, i.e. "borrowed borrowings". 


\section{Bibliography}

BRIGHT William, "Notes on Hispanisms", International Journal of American Linguistics 45.3, 1979: 267-271.

---, "Hispanisms in Southwest Indian languages", Romance Philology 53.2, 2000: 259-88.

CARNEY Ginny. 1997. Native American loanwords in American English. Wicazo Sa Review 12: 189-203.

Cutler Charles L., O Brave New Words! Native American Loanwords in Current English. Norman: University of Oklahoma Press, 1994.

LEON-PorTilla Miguel, "Algunos nahuatlismos en el castellano de Filipinas", Estudios de cultura nahuatl II, 1960: 135-8.

LozaNo Anthony Girard, “Aztec traces in Modern Spanish”. Hispania 64, 1981: 410-417.

MiLleR Wick R. "Early Spanish and Aztec Loan Words in the Indigenous Languages of Northwest Mexico", Homenaje a Jorge A. Suarez: Lingüística indioamericana e hispanica, ed. Beatriz Garza Cuarón and Paulette Levy. México D.F.: El Colegio de México, 1990: 351-365.

WATSON George, Nahuatl words in American English. American Speech 13, 1938: 108-121.

ZAMORRA Juan Clemente, "Amerindian loanwords in general local varieties of American Spanish”. Word 33, 1982: 159-171. 


\section{Appendix A \\ Alphabetical Catalogue of Nahuatl/Mexicano Loan Words in English}

Below is the complete list of ninety-three words having a clear Nahuatl origin according to the current online version of the Oxford English Dictionary, along with their dates of first attestation in English and the OED's definition:

ahuehuete, $n .1828$

A Mexican swamp cypress, Taxodium mucronatum (family Taxodiaceae), which can attain great girth and is important for the production of medicinal resins and timber.

\section{atlatl 1871}

A throwing-stick used by American Indians and Eskimos.

atole 1716

A kind of corn or other meal; gruel or porridge made of this.

axolotl 1786

A batrachian reptile (Siredon pisciforme, family Proteidæ) found in Mexican lakes, resembling the salamander in appearance, but, like all the Proteidæ, retaining throughout life the gills of its young state.

\section{avocado 1697}

a. The fruit of a West Indian tree (Persea gratissima); a large pear-shaped fruit, called also ALLIGATOR PEAR.

b. The green colour of the flesh of an avocado. In full, avocado green. Also as adj.

\section{cacao 1555}

1. The seed of a tropical American tree (Theobroma Cacao, family Byttneriaceæ), from which cocoa and chocolate are prepared.

W2. The powder produced by grinding the seeds, often with other substances mixed; also the drink prepared from the seeds or powder; $=\operatorname{COCOA} n$.

cacomistle 1869

A raccoon-like animal of the south-western United States and Mexico, Bassariscus astutus.

\section{camote 1842}

A name in Mexico and other Spanish-speaking countries for any one of several tuber-bearing plants, e.g. the sweet potato and yam.

\section{chalchuite 1843}

A green variety of turquoise from Mexico.

chayote 1884

Also chayota, cheyote. A vine, Sechium edule, native to tropical America and cultivated elsewhere for its fruit; the succulent squash-like fruit of this vine. Also called chocho.

chia, $n .^{2} 1832$

An annual, typically purple-flowering plant native to Mexico, Salvia hispanica (family Lamiaceae (Labiatae)), which is cultivated from the south-western United States to Argentina for its greyish, oily, mucilaginous seed, used in various foods and beverages and historically was a staple food of the Nahuatl people; (also) any of several similar plants of the genus Salvia, esp. S. columbariae. Freq. attrib., as chia oil, chia seed, etc. 


\section{Chicano 1947}

A. $n$. A person of Mexican birth or descent resident in the U.S. (particularly in those areas annexed in 1848), esp. one who is proud of his Mexican origins and concerned to improve the position of Mexicans in the U.S.; a Mexican-American.

B. adj. Of or pertaining to Mexican-Americans or to the varieties of English and Spanish spoken by them.See also: Chicana, Chicanismo

chicle, $n .1889$

In full chicle-gum: a gum-like substance obtained from the bully tree (Mimusops globosa), and from the sapodilla (Sapota zapotilla), largely used in the United States in the manufacture of chewing-gum; hence, chewing-gum. Hence 'chicle $v$. intr., to chew gum.

\section{chilli, chilly 1662}

1. a. The dried pod of species of Capsicum or Red Pepper, esp. C. annuum fastigiatum and frutescens. The pods, which are acrid, pungent, and of a deep red colour when ripe, are largely used as a condiment, and when reduced to powder form the basis of Cayenne pepper.

b. The shrub which bears chillies.

\section{chinampa 1832}

The native name of the floating-gardens formerly used on the lakes of Mexico, consisting of a wooden raft covered with earth.

chipotle, $n .1950$

A dried and smoked ripe jalapeño pepper, which is dark reddish-brown with a strong, piquant flavour, and is used esp. in Mexican cooking.

\section{chocolate 1604}

1. A beverage made from the seeds of the cacao-tree; now, as distinguished from cocoa, that made by dissolving chocolate cake (see next) in boiling water or milk.

2. A paste or cake composed of the seeds of the cacao-fruit roasted and ground, sweetened and flavoured with vanilla and other substances. This is used to make the beverage (sense 1), and also eaten in various comfits. Esp. a sweetmeat in the form of bars, cakes, or drops, often with a qualifying word (see quot. 1925). Also with $a$ and $p l$., a sweetmeat made entirely of or coated with chocolate. See also milk-chocolate.

3. Erroneously applied to the cacao-tree, its fruit or seed. Obs.

4. a. Chocolate colour.

b. as adj. Chocolate-coloured; dark brown; in U.S. spec. of certain soils.

\section{cocoa 1672}

W1. The seed of Theobroma Cacao, a tropical American tree: more correctly called CACAO. Obs. Formerly commonly called cocoa-nut, and now often cocoa-bean.

2. The Cacao-tree. (rare and improper.)

3. a. The powder produced by crushing and grinding the seeds, often with other substances added; also, a common beverage made from this powder, or from the prepared seeds. (The ordinary sense.)

b. A shade of brown resembling the colour of the powder. Also attrib.

colin $^{*} 1678$

The American quail or partridge; also called bob-white; in pl. the various species of the sub-family Odontophorinæ or Ortyginæ, to which this belongs.

\section{conepatl 1774}

An American skunk (genus Conep $\bar{a}_{t u s,}$ J. E. Gray, 1837).

\footnotetext{
* The pronunciation of this term was apparently recorded in error. See Appendix B for the OED's discussion.
} 


\section{copal 1577}

1. a. A hard translucent odoriferous resin obtained from various tropical trees, and from which a fine transparent varnish is prepared.

\section{coyote 1824}

a. Zool. The name, in Mexico and now in the United States, of the prairie- or barking-wolf (Canis latrans) of the Pacific slope of North America.

guacamole 1920

A Mexican dish made from avocado pears mixed with onions, tomatoes, chili peppers, and seasoning.

\section{guayule 1906}

A silver-leaved shrub, Parthenium argentatum, of the family Compositæ, native to northern Mexico and adjacent parts of Texas, formerly cultivated as the source of a type of rubber; also, the rubber produced from the plant.

\section{$\underline{\text { hule }} 1846$}

A Central American tree of the genus Castilloa (formerly Castilla), or the crude rubber obtained from it. So hu'lero, u'lero, a collector of rubber.

\section{istle 1883}

A valuable fibre obtained (in Mexico and Central America) from Bromelia sylvestris and species of Agave, as A. Ixtli, and used for cordage, nets, carpets, etc.

\section{jacal 1838}

A hut constructed of erect poles or stakes filled in with wattle and mud, a type common in Mexico and the south-western United States; an adobe house; also, the material or method used in building such a hut.

\section{jalap 1675}

1. A purgative drug obtained from the tuberous roots of Exogonium (Ipom $\boldsymbol{a}_{a}$ ) Purga and some other convolvulaceous plants; the active principle is the resin contained in the tubers (resin of jalap).

2. The Mexican climbing plant Exogonium Purga, with salver-shaped purplish flowers; also applied to some allied plants yielding a similar drug.

jalapeño 1949

Also jalapeño pepper. A very hot green chilli pepper, used esp. in Mexican-style cooking.

jicama, $n .1604$

The white, fleshy tuberous root of the yam bean as a vegetable that is eaten raw or cooked, esp. in salads. Also, the plant itself, a tropical leguminous vine, Pachyrhizus erosus, cultivated esp. in Central America.

\section{jicara 1859}

A Central American name for the calabash-tree (s.v. CALABASH 7) or its fruit (CALABASH 2).

\section{mazame, $n .1791$}

Any of various American deer and other ruminants, including the pronghorn, Antilocapra americana. Cf. MAZAMA $n .1$.

$\underline{\text { Mazatec }}, a d j$. and $n .1892$
A. adj. (attrib.). Of or relating to an American Indian people of northern Oaxaca in southern Mexico, or the language they speak.
B. $n$. 1. A member of the Mazatec people.
2. The Oto-Manguean language spoken by the Mazatecs. 
mecate, $n .1849$

1. A rope made of horsehair or of maguey fibre, used esp. to tether or lead a horse.

2. A measure of land formerly in use in the Yucatan region of Mexico, equal to about 0.04 hectare $(0.1$ acre). Obs.

imelt, $n^{2} 1605$

Obs. The maguey or American aloe, Agave americana.

mescal, $n .1709$

1. a. Any of various plants of the genus Agave, of Mexico and the south-western United States; esp. any of several large agaves with paniculate inflorescences, including those grown for ornament and hedging (e.g. the American aloe, A. americana), those whose bud, root, etc., is cooked as a vegetable (e.g. A. palmeri and A. parryi), and those whose fermented sap is distilled to produce an alcoholic spirit (the plant in this context being more commonly called maguey).

b. A strong intoxicating spirit distilled from the fermented sap of an agave. Cf. TEQUILA $n$, PULQUE $n$.

c. The cooked root, head, or bud of an agave used as food.

2. The button-like top of any of several small desert cacti of the genus Lophophora, esp. L. williamsii, of northern Mexico and southern Texas; a dried preparation of this, ingested for its intoxicating and hallucinogenic properties (chiefly attributable to the alkaloid mescaline); (also) a cactus having such top. Cf. PEYOTE $n$., mescal button $\mathrm{n}$. at Compounds 2.

mesquite, $n .1759$

1. a. Any of various thorny, pinnate-leaved, thicket-forming trees and shrubs of the genus Prosopis (family Mimosaceae (Leguminosae)), characteristic of arid regions of Mexico and the south-western United States (also mesquite tree); esp. P. glandulosa (more fully honey mesquite) and P. pubescens (more fully screw-pod mesquite). Also: the wood of any of these trees. Cf. MIZQUITL $n$.

b. Country dominated by mesquite trees; a thicket of mesquite trees.

metate, $n .1625$

In Central America and the southern United States: a flat or partly hollowed, usually oblong stone on which grain, cocoa, coffee, etc., is ground by means of a smaller stone. Also metate-stone. Cf. MANO $n .^{2}$

$\underline{\text { Mexican }}, n$. and $a d j .1578$

A. $n$.

1. A native or inhabitant of Mexico. In early use perh. also: ta native or inhabitant of Mexico City (obs.).

2. Any of the indigenous languages of Mexico; spec. $=$ NAHUATL $n$. Also: the form of Spanish used in Mexico.

3. U.S. colloq. Any piece of non-American (esp. Mexican) currency; spec. $=$ Mexican dollar $\mathrm{n}$. at Special uses 3b. Obs.

14. U.S. regional. $=$ Mexican sheep $\mathrm{n}$. at Special uses 1b. Obs.

5. A type of cotton cloth (see quot. 1910). Cf. Mexican cloth $\mathrm{n}$. at Special uses 1b.

B. adj. Of or relating to Mexico, its inhabitants, or its language.

milpa, $n .1648$

In Central America and Mexico: a small cultivated field, usually of corn or maize.

Mixe, $n$. and $a d j . a 1616$

A. $n$. 1. A member of an American Indian people of Oaxaca in southern Mexico.

2. Any of a group of related languages spoken by this people, which together form the Mixean branch of the Mixe-Zoque family; this group of languages.

B. adj. Designating, of, or relating to the Mixe or their languages. 
$\underline{\text { Mixteca, }} n$. and $a d j .1787$

A. $n$. 1. $=$ MIXTEC $n$. 1 .

$\operatorname{MIXTEC} n .1 .=$ A. $n$.

1. A member of an American Indian people of southern Mexico.

2. Any of the Otomanguean languages spoken by the Mixtecs.

B. $a d j .=$ MIXTEC $a d j$.

MIXTEC $a d j$. = B. $a d j$. Of, relating to, or characteristic of the Mixtecs or their languages.

$\underline{\text { Mixteco, }}, n$. and $a d j .1911$

A. $n$.

1. $=$ MIXTEC $n$. 2. [[See MIXTECA above--JDH]

2. $=$ MIXTEC $n$. 1. [[See MIXTECA above--JDH]]

B. adj. = MIXTEC adj.[[See MIXTECA above--JDH]]

Imizquitl, $n .1753=$ MESQUITE $n .1$ a.

molcajete, $n .1906$

A mortar, usually made of stone or clay, used in Mexican cooking for pounding spices.

$\underline{\text { mole, }}, n .^{7} 1891$

A highly spiced Mexican sauce made chiefly from chilli peppers and chocolate and served with various meats, esp. poultry. Also as postmodifier designating a dish made with this sauce.

Montezuma 1917

1. Montezuma quail $n$. a plump, short-tailed quail, Cyrtonyx montezumae (family Odontophoridae), native to the southern United States and Mexico, the male of which has a bold black and white facial pattern. Also called harlequin quail, Massena quail. Cf. Mearns quail n. at MEARNS $n .1$.

2. Montezuma's revenge $n$. (occas. also Montezuma revenge) slang diarrhoea suffered by travellers, esp. in Mexico.

nagual, $n .1822$

Among certain indigenous peoples of Mexico and surrounding countries: a guardian spirit in animal form, believed to accompany and guide an individual through life; an animal form believed to be assumed by a human through magical or supernatural means.

Nahua, $n$. and $a d j .1875$
A. $n$.
1. $=$ NAHUATL $n .1$
2. $=$ NAHUATL $n .2$. Cf. MEXICANO $n .2$.
B. $a d j .=$ NAHUATL $a d j$.

Nahuatl, $a d j$. and $n .1858$

A. adj. Of or relating to any of a group of American Indian peoples of southern Mexico and Central America, or their language.

B. $n$.

1. A member of any of the Nahuatl peoples.

2. The Uto-Aztecan language of the Nahuatl, usually regarded as a group of related regional varieties; the branch of the Uto-Aztecan language family constituted by these. Cf. MEXICANO n. 2 .

Nahuatlaca, $n$. and $a d j .1775$
A. $n$.
1. $=$ NAHUATL $n .1$
2. $=$ NAHUATL $n .2 . O b s$.
B. $a d j .=$ NAHUATL $a d j$. 


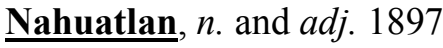
A. $n$.
1. $=$ NAHUATL $n$. 1. rare.
2. The branch of the Uto-Aztecan language family that includes Nahuatl.
B. adj. Of or relating to the Nahuatl peoples or their language.

nopal, $n .1578$

Any prickly pear cactus of the genus Opuntia (including the former genus Nopalea); esp. O. cochinellifera, formerly cultivated as a food plant of the cochineal insect. More fully nopal cactus.

Oaxacan, $n$. and $a d j .1897$

A. $n$. A native or inhabitant of the state or city of Oaxaca in southern Mexico.

B. adj. Of, belonging to, or characteristic of Oaxaca or its people.

ocelot, $n .1774$

1. A wild cat, Felis pardalis, having a tawny coat marked with numerous black rings, spots, and streaks, and found in forests and scrub from southern Texas to Argentina.

2. The skin or fur of the ocelot; a garment made of this. Freq. attrib.

ocote, $n .1787$

A pine tree of upland areas of Mexico and Central America, yielding very resinous wood; spec. Pinus oocarpa. Also: the wood of this tree. Freq. attrib.

octli, $n .1787$

Among the Aztecs: $=$ PULQUE $n$.

Olmec, $n$. and $a d j .1852$

A. $n$.

1. A member of an American Indian people inhabiting the coast of southern Veracruz and western Tabasco during the 15 th and 16 th centuries; = OLMECA $n$. 1 . Now hist. and rare.

2. Archaeol. A member of a prehistoric civilization, unrelated to the American Indian people, which flourished in the same area during the period $c 1500-400 \mathrm{~B}$.C. and is characterized by the style of its artefacts (see sense B. 2 and cf. OLMECA $n$. 2, OLMECAN adj.)

B. adj.

1. Of or relating to the American Indian Olmecs. rare.

2. Archaeol. Of or relating to the prehistoric Olmecs, their culture, or their characteristic artistic style, also found elsewhere in Southern Mexico. Cf. OLMECAN adj.

Olmeca, $n .1787$

1. A member of an American Indian people inhabiting the coast of southern Veracruz and western Tabasco in Mexico during the $15^{\text {th }}$ and $16^{\text {th }}$ centuries, to where they probably migrated during the $12^{\text {th }}$ cent. from the Mexican altiplano. Cf. OLMEC $n .1$.

2. Archaeol. A member of a prehistoric civilization of the same area; = OLMEC n. 2. rare.

ololiuqui, $n .1894$

A tropical American morning glory, Turbina corymbosa (family Convolvulaceae). Also: a psychoactive drug prepared from the seeds of this plant, used traditionally for ritual purposes by the Aztecs.

$\underline{\text { Otomi }}, n$. and $a d j .1782$
A. $n$.
1. A member of an American Indian people inhabiting parts of central Mexico.
2. Any of the related Oto-Manguean languages of this people.
B. adj. Of, relating to, or designating the Otomi or their language. 
oyamel, $n .1871$

A large fir tree, Abies religiosa, found at high altitudes in Mexico, and used in carpentry and as a source of turpentine and balsamic medicinal oil. More fully oyamel fir.

petaca, $n .1648$

In Mexico and South America: (originally) a basket or coffer lined or covered with leather; (later) a leather trunk, bag, or pack; a leather tobacco pouch.

petate, $n .1843$

In Central America and Cuba: a mat, esp. a sleeping mat, typically made of straw or dried palm leaves.

peyote, $n .1849$

1. A hallucinogenic drug made from the cactus Lophophora williamsii (see sense 2), containing mescaline and used esp. in some Native American rituals. Cf. MESCAL $n$.

2. The cactus Lophophora williamsii itself, a small, soft, spineless, blue-green cactus native to northern Mexico and southern Texas.

pinacate, $n .1895$

More fully pinacate beetle, pinacate bug. Any of several flightless black darkling beetles of the genus Eleodes found in the deserts of Arizona and northwestern Mexico, known for the foul-smelling liquid they emit when attacked. Cf. stink-bug n. at STINK $n$.

pinole, $n .1648$

1. Flour made from parched corn, usually sweetened with ground mesquite beans, cacao, or with sugar, originally used in Mexico and south-western United States.

2. A mixture of vanilla and other aromatic powders used to flavour chocolate. rare.

3. Chiefly in Central America: a drink made from ground maize and other ingredients, esp. chocolate.

posole, $n .1699$

1. In Mexican and Central American cooking: maize prepared by hulling, grinding, and boiling, for use in food or drink, hominy; (also) maize stew or soup made with this as the principal ingredient, typically also containing pork, beans, and red chilli.

2. A drink consisting of maize sourdough and water.

pulque, $n .1572$

A drink made in Mexico and some parts of Central America from the fermented sap of the agave or maguey (Agave americana); $=$ OCTLI $n$. Cf. MESCAL $n$. Although still made locally, pulque is rarely found outside the regions mentioned as the difficulty of storing and preserving it (see the etymology) renders export largely impracticable.

pupusa, $n .1948$

In the cuisine of El Salvador: a thick maize flour tortilla filled with various ingredients before being fried.

quamoclit, $n .1633$

Originally: the tropical American climbing plant Ipomoea quamoclit (family Convolvulaceae), with brilliant red flowers and deeply lobed leaves. Later also: (freq. with distinguishing word) any of various plants constituting the former genus Quamoclit; (also in form Quamoclit) the former genus itself. Quamoclit is now usually incorporated into the genus Ipomoea; it is still sometimes used as the name of a subgenus or section.

quetzal, $n .1800$

1. Any of several Central and South American trogons of the genus Pharomachrus, the males of which are noted for their iridescent green plumage with red or yellow underparts; esp. (more fully 
resplendent quetzal) P. mocinno of Central America, the male of which has extremely long tail coverts, and which was venerated by the Aztecs.

2. The principal monetary unit of Guatemala, introduced in 1925 and consisting of 100 centavos.

Quetzalcoatl, $n .1578$

The plumed serpent god of the Toltec and Aztec civilizations, traditionally known as the god of the morning star, as well as (at various times and among various peoples) the patron of priests, inventor of books and of the calendar, the god of wind, and the symbol of death and resurrection.

sacate, zacate 1848

Any of several grasses grown in Mexico, the southern U.S.A., and the Philippines, and used for hay or fresh forage; fodder made from such a grass. Cf. next.

\section{sotol 1881}

A plant of dry regions belonging to the genus Dasylirion of the family Agavaceæ, native to southwestern North America and bearing linear leaves and small white flowers; also, the fibre from the leaves of this plant or the beverage made from the sap.

\section{tacamahac, tacamahaca 1577}

1. An aromatic resin, used for incense, and formerly extensively in medicine. a. orig. That yielded by a Mexican tree, Bursera (Elaphrium) tomentosa. b. Extended in the West Indies and S. America to similar resins obtained from other species of Bursera and the allied genus Protium, and subsequently to resins imported from Madagascar, Bourbon, and the East Indies, chiefly the product of species of Calophyllum.

2. The resin of the buds of the N. American Balsam Poplar, Populus balsamifera; hence a name of this tree.

\section{Tecoma 1846}

A large genus of Bignoniacea, mostly natives of warm climates, consisting chiefly of shrubs (erect, climbing, or twining), with leaves usually pinnate, and showy trumpet-shaped flowers of various colours (chiefly different shades of yellow and red), whence the name trumpet-flower; many are cultivated in greenhouses, etc. for their beauty.

\section{teguexin 1879}

A large South American lizard of the genus Tupinambis or a similar member of the family Teiidæ.

\section{teocalli 1613}

A structure for purposes of worship among the ancient Mexicans and Central Americans, usually consisting of a four-sided truncated pyramid built terrace-wise, and surmounted by a temple.

\section{teonanacatl 1875}

Any of several hallucinogenic fungi, esp. Psilocybe mexicana, found in Central America. Also attrib.

\section{teopan 1891}

A Mexican temple, a teocalli.

\section{teosinte 1877}

An annual grass of Central America, Euchlcena luxurians, of large size, allied to maize; now widely cultivated as a valuable fodder plant, sometimes also as a cereal.

\section{tepache 1926}

Any of several Mexican drinks of varying degrees of fermentation, typically made with pineapple, water, and brown sugar.

\section{tilma 1851}


A kind of simple cloak or blanket secured with a knot, worn by the Indians of Mexico.

\section{tlachtli 1875}

The ceremonial ball-game of the Aztecs; = POK-TA-POK. Also attrib., as tlachtli-court, -field.

Tlapanec, $n$. (and adj.) 1875

a. An Indian people of south-west Guerrero, Mexico.

b. The language of this people, formerly classified as Hokan but now regarded as Otomanguean. Also attrib. or as adj. Also in Comb., as Subtiaba-Tlapanec (see SUBTIABA).

\section{toloache 1894}

A preparation of a plant of the genus Datura used as an intoxicating and hallucinogenic drug.

$\underline{\text { Toltec }}(n$. and $a$.) 1787

A. $n$. (A member of) a Nahuatl people who dominated the valley of Mexico $c$ 900-1150 A.D., before the arrival of the Aztecs.

B. adj. Of or pertaining to this people. Hence 'Toltecan $n$. and $a$. tomato 1604

1. a. The glossy fleshy fruit of a solanaceous plant (Solanum Lycopersicum or Lycopersicum esculentum), a native of tropical America, now cultivated as a garden vegetable in temperate as well as tropical lands. It varies when ripe from red to yellow in colour, and greatly in size and shape, the common form being irregularly spheroidal, while two smaller forms, considered by some as species, are named from their shape, L. cerasiforme, the cherry tomato, and L. pyriforme, the pear-shaped tomato. Formerly called love-apple, from supposed aphrodisiac qualities. Also the plant, an annual with a weak trailing or climbing stem, irregularly pinnate leaves, and yellow flowers resembling those of the potato.

\section{Totonac 1787}

An Indian people of east central Mexico; a member of this people. Also, their language. Also attrib. Hence Toto nacan $a$., of or pertaining to the family of languages that comprises Totonac and Tepehua.

\section{tule 1837}

a. Either of two species of bulrush (Scirpus lacustris var. occidentalis, and S. Tatora) abundant in low lands along riversides in California; hence, a thicket of this, or a flat tract of land in which it grows.

$\underline{\text { Zapotec }}, n$. and $a .1797$

A. $n$. A member of an American Indian people of southern Mexico.

B. adj. Of or pertaining to the Zapotecs.

Hence Zapo'tecan $a$. and $n$.

zopilote 1787

A vulture of the family Cathartidae, esp. the American carrion vulture or turkey-buzzard, Cathartes aura. 


\section{Appendix B}

\section{Etymological Notes for Nahuatl/Mexicano Loan Words in English}

The Oxford English Dictionary gives the following supplemental etymological notes for the Nahuatlderived loan words presented in Appendix A.

ahuehuete, $n .1828$ [Mex. Sp., ad. Nahuatl ahuehuetl, f. huehue old + atl water.]

atlatl 1871 [Indian (Nahuatl) atlatl spear-thrower.]

atole 1716 [Amer.-Sp., f. Nahuatl atolli.]

axolotl 1786 [the Aztec name.]

avocado 1697 [Sp. avocado advocate, substituted by 'popular etymology' for the Aztec ahuacatl (Tylor), of which a nearer form in $\mathrm{Sp}$. is aguacate; F. aguacat and avocat, in Eng. also avigato and, corruptly, alligator (pear).]

cacao 1555 [Sp. cacao, ad. Mexican caca-uatl 'caca-tree'.]

cacomistle 1869 [Amer. Sp. cacomixtle (also used), f. Nahuatl tlacomiztli.]

camote 1842 [Mexican Sp., ad. Nahuatl camotli.]

chalchuite 1843 [f. the Mexican name of the stone, chalchihuitl + -ITE.]

chayote 1884 [a. Sp. chayote, ad. Nahuatl chayotli.]

chia, $n .^{2} 1832[<$ Mexican Spanish chia, name of several different plants of the family Lamiaceae (1560) and its etymon Nahuatl chia, chian.]

Chicano, $n$. and adj. 1947 [a. Mexican Sp. alteration of Sp. mejicano Mexican.]

chicle, $n .1889$ [Amer. Sp., ad. Nahuatl tzictli.]

chilli, chilly 1662 [In Sp. chile, chili, a. Mexican chilli, the native name in 16thc. Simeon Dict. Langue Nahuatl, has 'Chilli, piment dont on compte douze espèces principales; il sert à composer avec le maïs une boisson très-recherchée chilli atolli, chillatolli'. So 'chilatl eau de chilli', etc. As early as 1631, Bontius erroneously stated that the name was from Chile in S. America 'quasi dicas piper a Chile'.]

chinampa 1832 [Mexican: orig. 'raft'.]

chipotle, $n .1950$ [ $<$ Mexican Spanish chipotle (1976 or earlier; 1953 or earlier as chilpocle; also as

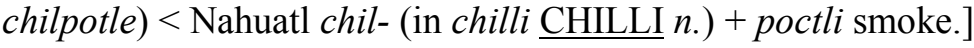

chocolate 1604 [a. F. chocolat, Sp. chocolate, ad. Mexican chocolatl 'an article of food made of equal parts of the seeds of cacao and those of the tree called pochotl' [Bombax ceiba] Siméon Dict. de langue Nahuatl. Chocolatl has no connexion whatever with the Mexican word cacauatl 'cacao', or its modern corruption cocoa; but is, so far as is known, a radical word of the language. It is possible, however, that Europeans confounded chocolatl with cacaua-atl, which was really a drink made from cacao.]

cocoa 1672 [A corruption of CACAO, in 16-18th c. also written cacoa, and sometimes in 18th c. cocao. Cacao was the Spanish adaptation of cacauatl (or rather of its combining form cacaua-), the 
Mexican name of the cacao-seed. The word was orig. of 3 syllables, $c a^{\prime}-\mathrm{ca}-\mathrm{o}, \mathrm{co-}-\mathrm{co}-\mathrm{a}$, but the error of spelling coco as cocoa has led to the further corruption of pronouncing cocoa as coco.]

\section{colin 1678}

[Given by Hernandez as the ancient Mexican name of the genus Ortyx and its congeners. But the actual Mexican word was çolin or zolin; Molina, Vocab. Mexicano y Castellano (Mexico, 571) has 'Çolin, codorniz'. Colin was thus app. an erroneous form, due to omission of the cedilla in printing. From the work of Hernandez (a1628) it passed into those of Nieremberg (1635), Willughby (1676), Ray (1678), Buffon, etc. It has no connexion with the Fr. Colin a popular name of a sea-gull (Belon, Hist. Nat. Oyseaux, 1555), with which it has by some been confused.]

conepatl 1774 [Native Mexican name: lit. 'little fox'; f. conetl, in comp. cone- 'child', prefixed to names of animals $=$ 'young, little' + epatl fox. (Siméon.)]

copal 1577 [a. Sp. copal (F. copal, copale), ad. Mexican copalli incense (Molina, 1571), a fragrant translucent white resin which distils from a tree, thence called copalquahuitl, also by extension applied to any similar resin (Hernandez, 1651, III. i.).]

coyote 1824 [a. Mexican Sp. coyote, ad. native Mexican coyotl.]

guacamole 1920 [Amer. Sp. guacamole, ad. Nahuatl ahuacamolli, f. ahuacatl avocado + molli sauce.]

guavule 1906 [a. Amer. Sp. guayule, f. Nahuatl cuauhuli.]

hule 1846 [Mexican Sp. (h)ule, Nahuatl ulli or olli caoutchouc.]

istle 1883 [Commercial corruption of the Mexican name ixtli.]

jacal 1838 [Mexican Sp., ad. Nahuatl xacalli.]

jalap 1675 [= F. jalap, ad. Sp. jalapa, in full purga de Jalapa, from Jalapa formerly Xalapa, a city of Mexico, in Aztec Xalapan (pronounced Ja'la'pan), lit. 'sand by the water' f. xalli sand + atl water + pan upon. (Skeat in Trans. Philol. Soc. 1889.) Aztec names in -an, with accent on penult, uniformly lost the $n$ in Spanish.]

jalapeño 1949 [Mexican Sp. (chile) jalapeño Jalapa chilli: see JALAP n.]

iicama, $n .1604$ [Mexican Sp. jicama, ad. Nahuatl xicama.]

jicara 1859 [Amer. Sp. jicara, jícaro, ad. Nahuatl xicalli.]

mazame, $n .1791$ [< French mazame (a1789 in Buffon) < Nahuatl maçame (recorded a1587 by Francisco Hernandez, as is temamaçame (compare quot. 1791 at main sense)), plural of maçatl deer. Compare Mexican Spanish mazate, from the singular form of the Nahuatl word. N.E.D. (1906) follows e.g. Cent. Dict. in giving the anglicized pronunciation $\left(\mathrm{m}^{\mathrm{Z}} \mathrm{Z}^{\overline{e^{i}}} \cdot \mathrm{m}\right) / \mathrm{m}^{\mathrm{z}^{\prime}} \mathrm{ze} \mathrm{m} /$ (which is now rare or obs.), but notes that 'the original word is' (mas $\left.{ }^{\overline{\mathrm{a}}} \cdot \mathrm{m} e\right) / \mathrm{ma}^{\prime} \mathrm{s}^{\mathrm{a}} \mathrm{me}$. Compare MAZAMA $n$.]

Mazatec, adj. and n. $1892[<$ Spanish Mazateca < Nahuatl masa:te:ka < masa: deer +-te:ka ending denoting 'inhabitant of the place of $-{ }^{'}$.]

mecate, $n .1849[<$ Mexican Spanish mecate $<$ Nahuatl mecatl cord, rope.]

Tmelt, $n .^{2} 1605$ [<Middle French melt $(1584)<$ Nahuatl metl (1541 in Spanish texts from Mexico).] 
mescal, $n .1709$ [ $<$ American Spanish mescal, mexcal, mezcal (app. earliest $c 1745$ in a compound ethnonym: see MESCALERO $n$.) and its etymon Nahuatl mexcalli (1577 in sense "cooked (pieces of) agave leaf'; now only in sense 1b). N.E.D. (1906) records only a pronunciation with stress on the second syllable. The pronunciation with stress on the first syllable which is now the commonest in British usage probably arises from analogy with MESCALINE $n$.]

mesquite, $n .1759$ [< Mexican Spanish mezquite (1591; 1577 in form mizquite) < Nahuatl mizquitl MIZQUITL. It is uncertain whether the form in quot. 1572 at sense 1a, which is earlier than the first attestation in Spanish and considerably earlier than those in English, represents the same word. The unusual form mesketis (only attested in the compound form mesketis-bush: see quot. 1887 for mesquite bush n. at Compounds 1a) is perhaps intended as a plural. N.E.D. (1906) also gives an alternative pronunciation, with the stress on the first syllable $\left(\mathrm{me} \cdot \mathrm{sk}^{\overline{\bar{t}_{\mathrm{t}}}}\right) / \mathrm{m}^{\boldsymbol{\varepsilon}_{\mathrm{ski}} \mathrm{t} \mathrm{t} / \text {.] }}$

metate, $n .1625[<$ Mexican Spanish metate, métlatl (both 1577 in a Spanish text from Mexico) < Nahuatl metlatl.]

Mexican, $n$. and adj. $1578[<$ Spanish mexicano, noun and adjective (1541, now obs. in this form except in American Spanish; 1608 in form mejicano; 16th cent. in lengua mexicana denoting Nahuatl) $<$ México, the name of a country in Central America and (orig.) of the city which is its capital (151926; of uncertain origin: perhaps $<$ Nahuatl Mexitli one of the names of the Aztec god of war) + -ano = AN suffix. In form Mexicaines in quot. 1604 at sense A. 1, probably after French Mexicain (1588 in Middle French as noun; also as noun and adjective in Middle French in forms Mexican (1588) and Mexicquain (1584)).]

milpa, $n .1648[<$ Mexican Spanish milpa (1568 in this sense; 1552-3 in plural form milpas in sense 'property, estates') < Nahuatl milpan < mil- (in milli cultivated field) + -pan (postposition) on the surface of, in, on.]

Mixe, $n$. and adj. a1616 [< Mexican Spanish mixe, noun (1526; 1674 in form mije) and adjective (1729 or earlier), perhaps $<$ Nahuatl $m^{\overline{\bar{i}}} x^{\bar{z}}$ - (in $m^{\overline{\bar{z}}} x^{\bar{i}} t l$ an intoxicating herb).]

Mixteca, $n$. and adj. 1787 [ $<$ Spanish mixteca (1541; also 1545 asmisteca) $<$ Nahuatl mixtecah, lit. 'people from a cloudy location'. Compare Italian Mixtechi, plural (1780 in the passage translated in quot. 1787 at sense A. 1).

The Mixteca is frequently used as the name of the region in western Oaxaca where this people lives.]

Mixteco, $n$. and adj. $1911[<$ Spanish mixteco $(1541$; also 1629 as misteco) $<$ Nahuatl mixtecah (see MIXTECA $n$. and $a d j$.$) .]$

Imizquitl, n. 1753 [< Nahuatl mizquitl, perhaps after Mexican Spanish mizquitl (in A. de Molina Vocabulario en Lengua Castellana y Mexicana (1571)).]

molcajete, $n .1906$ [< Mexican Spanish molcajete $(1827)<$ Nahuatl mo:lcaxitl.]

mole, $n{ }^{7} 1891[<$ Mexican Spanish mole $(1577)<$ Nahuatl mo:lli sauce, broth, gravy, mole.]

Montezuma $[<$ the name of Montezuma II (1466-1520), Aztec ruler at the time of the Spanish conquest of Mexico. In sense 1, after scientific Latin montezumae, specific name of Ortyx (now Cyrtonyx) montezumae (N. A. Vigors 1830, in Zool. Jrnl. 5 275).]

nagual, $n .1822$ [ $<$ Mexican Spanish nagual, nahual sorceror, companion < Nahuatl nahualli guardian spirit residing in an animal.]

Nahua, $n$. and $a d j .1875[<$ Nahuatl Nahua, stem form and plural of Nahuatl NAHUATL adj. and $n .<$ nahua sonorous, pleasing to the ear.] 
Nahuatl, $a d j$. and $n .1858$ [< Spanish Náhuatl and its etymon Nahuatl Nahuatl, lit. 'person or thing that pleases the ear' < Nahua (see NAHUA $n$. and $a d j$.) $+-t l$, singular noun suffix. Compare earlier NAHUATLACA $n$. and $a d j$.

Modern Nahuatl is divided into three regional groups: the central and northern Aztec dialects retain the consonant group $t l$ (hence the form Nahuatl); the eastern Aztec dialects have replaced the consonant group $t l$ with $t$ (hence the form Nahuat); while the western dialects have replaced the consonant group $t l$ with $l$ (hence the form Nahual).]

Nahuatlaca, $n$. and adj. $1775[<$ Nahuatl Nahuatlaca, stem form and plural of Nahuatlacatl a Nahuaspeaking person $<$ Nahua (see NAHUA $n$. and $a d j$.) + tlaca person $+-t l$, singular noun suffix. With form Nahuatlaque (see quot. 1858 at sense A. 2) compare French Nahuatlaque (1811 in passage translated in quot. 1811 at sense A. 1).]

Nahuatlan, $n$. and adj. $1897[<$ NAHUATL $n$. + -AN suffix.]

nopal, $n .1578$ [ $<$ Spanish nopal (1552 in the passage translated in quot. 1578 at main sense) $<$ Nahuatl nopalli cactus, collective name for all Opuntia species. Compare NOPALES $n$. Compare (< Spanish) French nopal (1584), Portuguese nopal (18th cent.), Italian nopale.

The Nahuatl compound nopalnocheztli, given in some dictionaries as the source of nopal or Nopalea, is in fact the name for cochineal (Nahuatl nochetztli $<$ nochtli Opuntia + eztli blood).

Oaxacan, $n$. and adj. 1897 [< the name of Oaxaca (Spanish Oaxaca, Nahuatl Hua:xacac), a city and state in Southern Mexico + -AN suffix.]

ocelot, $n .1774[<$ French ocelot (1765 in Buffon) < Spanish ocelote and its etymon Nahuatl ocelotl jaguar (1571 in A. de Molina Vocabulario en Lengua Castellana y Mexicana). Nahuatl tlalocelotl, lit. 'field jaguar' (< tlalli earth, field + ocelotl jaguar) is first recorded in Francisco Hernández Noua Plantarum, Animalium et Mineralium Mexicanorum Historia (1651), but ocelotl had already been cited in a French text as an Aztec word by J. de Laet L'Hist. du Nouveau Monde (1640). Ocelotl is recorded earlier in English as the name of a day (represented by the tiger or jaguar) in the ancient Aztec calendar. Compare:

ocote, $n .1787[<$ Mexican Spanish and Central American Spanish ocote (1541 or earlier) $<$ Nahuatl ocotl pine (Pinus), torch or kindling made from this. In quot. 1787 translating Italian Ocote (1780). The Nahuatl form ocotl is also occas. found in historical English contexts, with reference to the use made of it by the Aztecs. ]

octli, $n .1787$ [ $<$ Nahuatl octli alcoholic drink, the fermented juice of the maguey, pulque.]

Olmec, $n$. and adj. 1852 [In senses A. 1 and B. 1 shortened either < Nahuatl Olmeca OLMECA $n$., or directly $<$ OLMECA $n$. In senses A. 2 and B. 2 partly after Spanish Olmego (see OLMECAN adj.).]

Olmeca, $n .1787$ [ $<$ Nahuatl Olmeca (plural of Olmecatl), lit. 'inhabitants of the rubber country', with reference to the rubber trees which grew abundantly in this region of the Mexican Gulf Coast. Compare Italian Olmechi, plural (1780 in the passage translated in quot. 1787 at sense 1).]

ololiuqui, $n .1894$ [ $<$ Nahuatl ololiuhqui, lit. 'round thing', referring to the spherical seeds of the plant (1651 in Francisco Hernández Noua Plantarum, Animalium et Mineralium Mexicanorum Historia) < olol- round, spherical + -iuhqui, suffix meaning 'like'. In form ololiuque after Spanish ololiuque (1942).]

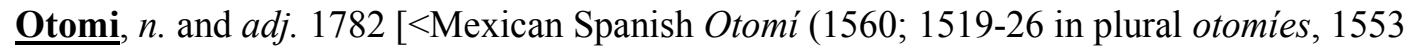

as otomix denoting the people, otomitlh, otomilh denoting the language) $<$ Nahuatl otomih, plural of otomitl. With the form Othomi compare Spanish othomi (1770 in an isolated attestation).] 
oyamel, $n .1871$ [ $<$ Mexican Spanish oyamel < Nahuatl oyametl fir tree (1571).]

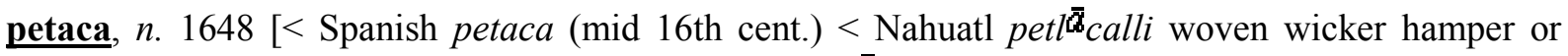
coffer, perhaps $<$ petlatl woven mat (see PETATE $n$.) $+\bar{a}_{\text {calli boat.] }}$

petate, $n .1843[<$ Spanish petate $(1541$ or earlier $)<$ Nahuatl petlatl. $]$

peyote, $n .1849$ [ $<$ Spanish peyote (17th cent.; in 20th cent. also peyotl) and its etymon Nahuatl peyotl peyote cactus.]

pinacate, $n .1895$ [ $<$ Mexican Spanish pinacate < Nahuatl pinacatl (both 1571 in A. de Molina Vocabulario en lengua castellana y mexicana).

Compare the following earlier isolated borrowing of Nahuatl pinacatl via Italian pinacatl (1780 in the passage translated in the following quot.): 1787 C. CULLEN tr. F. S. Clavigero Hist. Mexico I. I. 67 The beetles are of several kinds, and mostly harmless. Some of them are of a green colour, and are called by the Mexicans, Majatl. There are others black, of a disagreeable smell and irregular form, which are called Pinacatl.]

pinole, $n .1648$ [ $<$ Spanish pinole maize flour, a drink made from this $(1591 ; 1576-1577$ as pinolli, also as pinol (16th cent. in the passage translated in quot. 1917 at sense 2, subsequently from the 20th cent.)), aromatic powder $(1737)<$ Nahuatl pinolli maize flour for making drinks, the drink made from this.]

posole, $n .1699$ [ $<$ Mexican Spanish pozole (1775-6 or earlier; also in forms posol, posole, pozol) and its etymon Nahuatl pozolli stew or drink based on maize (see below). In quot. 1699 at sense 1 perhaps directly $<$ Nahuatl, although the Anglicized form poorsoul mentioned in it suggests an intermediate disyllabic form such as is found in Spanish. This form is probably unconnected with later (rare) U.S. regional poor soul in sense 'corn dumpling'.]

pulque, n. 1572 [< Central American Spanish pulque (1524), probably < Nahuatl puliuhki decomposed, spoiled (in octli puliuhki spoiled octli, octli being the name of the drink in Nahuatl: see OCTLI $n$.), spec. sense development of poliuhki, puliuhki lost, condemned (1571 as poliuhqui in A. de Molina Vocabulario en lengua castellana y mexicana). It is likely that octli puliuhki, referring to spoiled pulque, was frequently used in Nahuatl (given that pulque easily spoils if not drunk within 24 to 36 hours), and that the adjective was then misapprehended by Spanish speakers as the name of the drink. See further J. Corominas Diccionario crítico etimológico castellano e hispánico (1981) s.v. and C. A. Robelo Diccionario de Aztequismos (ed. 3, c1950) 450-4. Compare French pulque (1765). N.E.D. (1909) gives the non-naturalized pronunciation $(\mathrm{pu} \cdot \mathrm{lke}) / \mathrm{pulke} /$.

pupusa, $n .1948$ [ $<$ American Spanish (El Salvador) pupusa tortilla made with maize or rice flour and filled with pork cracklings, cheese, or other ingredients (1916; also popusa) < Pipil pupu:sah (ult. < Nahuatl popōtzōa to puff out, thicken, swell), the tortilla being so called on account of its shape. Pipil is an Aztecan language spoken by a now very small number of people in El Salvador; it is descended from Nahuatl.]

quamoclit, $n .1633$ [< post-classical Latin quamoclit (1588 (in the source referred to in quot. 1633) or earlier; also 1611 or earlier as quamochlit $<$ Nahuatl qua'mochitl $(c h=/ \mathrm{t} / /)(\mathrm{R}$. Siméon Dictionnaire de la langue Nahuatl (1885); not recorded in modern dictionaries of Nahuatl), app. < qua- (in quauitl (now cuahuitl) tree) + -mochitl, of unknown meaning (not otherwise recorded in dictionaries of Nahuatl). Adopted into scientific Latin as a specific epithet (Linnaeus Species plantarum (1753) I. 159) and later used as a genus name (C. Moench Methodus Plantas Horti Botanici et Agri Marburgensis (1794) 453).] 
quetzal, $n .1800$ [ $<$ Mexican Spanish quetzal (a1575 in the source translated in quot. 1800 at sense 1) $<$ Nahuatl quetzalli a tail-feather of the bird called quetzaltototl $(<$ the combining form of quetzalli + tototl bird). Compare the following earlier use of the Nahuatl word in an English context: 1625 tr. in S. Purchas Pilgrimes II. V. vii. 1096 Item, 80. handfuls of greene rich feathers, which they call Queçaly.]

Quetzalcoatl, $n .1578$ [< Nahuatl quetzalli (see QUETZAL n.) + coatl snake; orig. via Spanish Quetzalcóatl (1554 in the passage translated in quot. 1578 as Queçalcouatlh). Compare Middle French Quezalcoatl (1584; also Quezalconatl, Quezalcoconatl).]

$\underline{\text { sacate, }} \underline{\text { zacate }} 1848$ [ad. Mexican Sp. zacate grass, hay, ad. Nahuatl çacatl, zacatl grass, reed.]

sotol 1881 [Amer. Sp., f. Nahuatl tzotolli.]

tacamahac 1577[ad. obs. Sp. tacamahaca, in Hernandez 1614 thecomahaca, ad. Aztec tecomahiyac; mod.Sp. tacamaca. Cf. Monardes 1579 'ex Nova Hispania..ab Indis tacamahaca vocatum'. In F. tacamaque. Tacamahac is the more usual form, and that recognized in North America in sense 2.]

Tecoma 1846 [mod.L. (Jussieu 1789), from Aztec tecomaxochitl, mistakenly supposed by Jussieu to be the name of a species of the genus to which he gave this name (but really the native name of Solandra guttata, N.O. Solanacee). The Aztec name is a compound of tecomatl + xochitl 'rose, flower'; the plant being named from the resemblance of its flower to that of the tecomatl or Calabashtree (Crescentia Cujete, N.O. Bignoniacece), lit. 'pot-tree', f. tecomatl earthen vessel, pot.]

teguexin 1879 [ad. Aztec tecoixin, tecouixin, a lizard.]

teocalli 1613[Mexican teocalli, f. teotl god + calli house.]

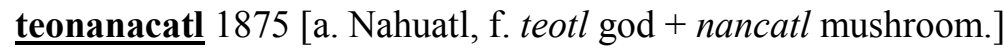

teopan 1891 [Shortened from Mex. teo-, teupantli temple, f. teotl god + pantlí wall.]

teosinte 1877 [In F. téosinté (Bull. Soc. d'Acclim. 1871, 38), ad. Mex. teocintli 'seu spica Maizii montana' (Hernandez Op. 1790, II. 120), app. f. teotl god + cintli, centli dry ear or cob of maize. In Ramirez Sinon. Plant. Mex. 67 teoxintli.]

tepache 1926 [Mexican Sp., ad. Nahuatl tepiatl.]

tilma 1851 [Mexican Sp., ad. Nahuatl tilmatli, in comb. tilma-.]

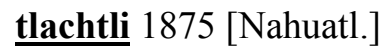

Tlapanec, $n$. (and adj.) 1875 [ad. Sp. tlapaneca, tlapaneco, ad. Nahuatl (Aztec) tlapanecatl.]

toloache 1894 [a. Mexican Sp. toloache, a. Nahuatl toloatzin, f. toloa to bow the head + tzin reverential.]

$\underline{\text { Toltec }}(n$. and $a)$.1787 [ad. Sp. tolteca, ad. Nahuatl toltecatl, pl. tolteca.]

tomato 1604 [In 17th c. tomate, a. F. tomate (2 syll.) fem., or Sp. and Pg. tomate (3 syll.) masc., ad. Mex. tomatl. Tomato is an English alteration, app. assumed to be Spanish, or perh. after potato; tomata a later change, app. assuming a Sp. *tomata like patata; tomatum, -us are erroneous latinizations.

Totonac 1787 [ad. Sp. Totonaca, f. Nahuatl Totonacatl, pl. Totonaca.] 
tule 1837 [ad. Aztec tullin, the final $n$ being dropped by the Spaniards as in Guatemala, Jalapa, etc.]

Zapotec, $n$. and a. 1797 [ad. Sp. zapoteco, zapoteca, ad. Nahuatl tzapoteca, pl. of tzapotecatl, lit. 'person of the place of the sapodilla'.]

zopilote 1787 [Sp., a. Mexican azopilotl.] 


\section{Appendix C \\ English Borrowings Improbably Attributed to Nahuatl}

The OED lists two English words as possible Nahuatl loans but for which I find a lack of compelling evidence to support such a conclusion. These are marijuana and Subtiaba. I will give the OED entries for and discuss each in turn. The OED definition for marijuana is as follows:

\section{marijuana, $n .1894$}

1. a. A preparation of the cannabis plant Cannabis sativa subsp. indica, for use as an intoxicating and hallucinogenic drug; esp. a crude preparation of the dried leaves, flowering tops, and stem of the plant in a form for smoking. The currency of the word increased greatly in the United States in the 1930s in the context of the debate over the use of the drug, the term being preferred as a more exotic alternative to the familiar words hemp and cannabis.

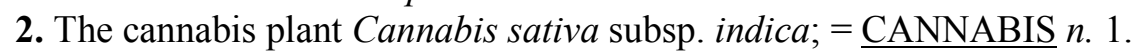

The OED's etymological notes state the following:

marijuana, $n *{ }^{*} 1894$ [< Mexican Spanish mariguana, marihuana, of uncertain origin. It has been suggested that the Spanish word is $<$ Nahuatl mallihuan prisoner. Forms in $-j$ - appear to be an English innovation (attested later also in French): occasional recent examples in Spanish probably show English influence. Influence of a folk etymology from the Spanish personal name María-Juana or its familiar form Mari-Juana has frequently been suggested; if so this would appear to have occurred within English.]

That the English word is derived from the Spanish, and that its use was promoted to "exoticize" it (and its users), is not in doubt. What I would like to question here, however, is any connection to the Nahuatl term mallihuan 'prisoner'. While the phonetic forms of these two words are indeed similar, I see no semantic basis for connecting the two terms. The connection of this plant with illegality and hence 'prisoners' is something that only occurred later. Therefore, I regard this as a case of accidental homophony and, until additional positive evidence is brought forth, I reject marijuana as being a possible Nahuatl loan word. The second term is Subtiaba, defined as follows:

\section{Subtiaba 1891}

a. (A member of) an Indian people of western Nicaragua.

b. The Tlapanec language of this people (no longer spoken), formerly considered to have Hokan affinities but now regarded as Otomanguean. Formerly also Subti'aban. Also Comb., as SubtiabaTlapanec, a group of related central American Indian languages, including Subtiaba.

Subtiaba 1891 [The name of a village, (San Juan Bautista de) Subtiaba, earlier Sutiaba, (see quot. 1891): perh. of Nahuatl origin.]

I doubt the etymology given for this word on the basis of its not having characteristic Nahuatl-derived phonology. For example, where does the phoneme /b/ come from? Also, the word-medial /bt/ consonant cluster is quite unusual. While it might be possible that such a form is ultimately derived from Nahuatl, I would like to see positive evidence presented in favor of such a conclusion. 


\section{Appendix D \\ English Borrowings Previously But Spuriously Connected to Nahuatl}

The OED gives the following etymological discussions which involve previous attributions of entries to a Nahuatl origin, but which are now known to either be spurious or are otherwise placed in serious doubt.

\section{tmesteque 1667}

Obs. A kind of fine, dark-grained cochineal.

[Origin uncertain. Perhaps < a Mexican toponym (compare quot. $a 1589$ at main sense), perhaps < Misteca (from 1558 in Spanish sources), variant of Mixteca, the name of the ancient Mexican province corresponding to the present Oaxaca (compare MIXTEC $n$.), although this would not accord well with the geography implied in quot. a1589 at main sense. Compare Spanish cochinilla mestiza denoting a variety of the cochineal insect (1787 in E. Terreros y Pando Dicc. Castellano; in a cross-reference given also in spelling mestica).]

mitla, n. $a 1925$.

An unidentified mammal said to inhabit forests on the borders of Bolivia and Brazil. [Origin unknown. Nahuatl mitla 'fortified hilltop' is unconnected.]

pauxi, $n .1678$

Any of several curassows. Now chiefly (in form Pauxi): a genus comprising the (northern) helmeted curassow, Pauxi pauxi, of Venezuela and Colombia, and the related P. unicornis.

[Origin uncertain; perhaps < post-classical Latin pauxi (see below) or American Spanish pauxí (1605 in an Ecuadorian source), pauji (1629 in a Central American source from Guatemala or Honduras), perhaps ult. < either Quechua or a Mayan language. Compare also (in a Cariban language) Chaima paoxi bird, which may however be $<$ American Spanish. It has also been suggested that the name is a local derivative of Spanish pavo turkey. Compare scientific Latin Pauxi (or Pauxis: see note below). Compare also POWIS $n$. The word was recorded $a 1587$ by Francisco Hernandez, app. as a local Mexican (Nahuatl) name; no evidence of Nahuatl origin has however been found. Compare the following earlier examples of post-classical Latin pauxi, perhaps representing the ablative corresponding to a nominative pauxis (the works of F. Hernandez (1517-87) were chiefly published posthumously):

1635 J. EUSEBIUS NIEREMBERGIUS Hist. Nat. X. 1xxv. 233 De pauxi. Pauxi gallinaceum aequat aut superat... Ad aulam Philippicam allatam pauxin sic describit Franciscus Hernandus. 1649 F. HERNANDEZ Rerum Medicarum Thes. II. ccxxii. 56 (heading) De Pauxi vocata ave.

Valid publication as a genus name: C. J. Temminck in Hist. Nat. Gén. des Pigeons et Gallinacés (1813) II. 456, after earlier valid publication as specific name (in the genus Crax) by Linnaeus in Systema Naturae (ed. 12, 1766) 270. The genus name was spelt Pauxis by some 19th-cent. writers. American Spanish pauji is now used, usu. with distinguishing word, for various species of curassow.] 


\section{Appendix E \\ Indigenous Mexican Loanwords, Possibly of Nahuatl Origin}

The following terms are listed as deriving from Mexican Spanish by the Oxford English Dictionary, and in some cases further note is made that they are ultimately of indigenous Mexican origin. I include them here because they could possibly involve a Nahuatl origin, although I have no positive evidence that they do. I leave the issue of confirmation one way or the other for future research.

\section{amole 1831}

The root or bulb of any one of several plants found in Mexico and California, used as a detergent; also any of such plants, esp. Chlorogalum pomeridianum, called also soap-plant (see SOAP $n$. 6b). Also attrib.

[Mexican Sp.]

$\Rightarrow$ Watson (1938: 120) suggests the following Nahuatl etymology for amole:

$\underline{\text { amole }}<$ Nah. amolli $-a$ - 'water' + -molli 'a saponaceous vegetable substance'

\section{copalche 1866}

A shrub of Mexico and Central America, Croton pseudo-China or niveus, family Euphorbiaceæ, yielding the copalchi-bark, used as a febrifuge, as a substitute for quinine; also a Brazilian tree Strychnos pseudo-China, to the bark of which the same properties have been ascribed.

[The native Mexican name.]

\section{mariachi 1929}

A. $n$. A small group of Mexican strolling musicians who perform traditional folk music; any band performing the type of music associated with such groups; the music played by such musicians. Also: a member of such a group; a Mexican folk musician.

B. adj. Of, relating to, or designating mariachis or the type of Mexican folk music associated with mariachis.

[< Mexican Spanish mariachi (also in form mariache) street musician, mariachi musician (1852 in sense

'open-air entertainment involving music and dancing'), further etymology uncertain. The word is plausibly attributed to the former Uto-Aztecan language of the district of Cocula in the Mexican province of Jalisco, where modern mariachi music originated. See H. Rafael Origen e Historia del Mariachi (ed. 2, 1983), 63 ff.]

\section{palapa 1957}

A traditional Mexican rustic shelter, roofed with palm leaves or branches; (also) the palm leaves or branches used in such a construction. Hence: any structure built in imitation of this, esp. on a beach. [ $<$ Mexican Spanish palapa (c1975 in sense 'shelter roofed with palm leaves or branches'; 1929 or earlier in sense 'leaves or branches of the tree Orbignya cohune'), of unknown origin.]

saguaro 1856

A large branching cactus, Carnegiea gigantea, found in desert regions of southwestern North America.

[? Mexican.]

shack, $n .^{3} 1878$

1. a. A roughly built cabin or shanty of logs, mud, etc. Also applied to other similar structures.

[Of obscure origin. The late J. Platt, Jun., suggested (N. \& Q. Ser. x. XII. 306/2) that the source might be the Mexican jacal, Aztec xacalli, wooden hut. Cf. SHACKLE $\left.n .{ }^{3}\right]$

tamal 1856

A Mexican delicacy, made of crushed Indian corn, flavoured with pieces of meat or chicken, red pepper, etc., wrapped in corn-husks and baked. 
[Mexican Sp. ta'mal, pl. tamales (-'ales).]

$\Rightarrow$ Watson (1938: 117) suggests the following Nahuatl etymology for tamal: tamal or tamale (earlier tamauli) $<$ Nah. tamalli (cp. nixtamal - See Appendix G)

\section{tapayaxin 1753}

The orbicular horned lizard, Phrynosoma orbiculare, incorrectly called the horned frog or toad.

[Native Mexican.]

\section{tequila 1849}

a. A gin-like Mexican spirit made by distilling the fermented sap of a maguey, Agave tequilana; cf. MESCAL.

[a. Mexican Sp., f. the name of a town which is one of the centres of its production.] $\Rightarrow$ Watson (1938: 118) suggests the following Nahuatl etymology for tequila:

tequila (or tequela) $<$ Mexican city Tequila,$<$ Nah. Tequilan 'the place of the divide'

\section{toyon 1876}

The Californian Holly, Heteromeles (Photinia) arbutifolia, N.O. Rosacece. [a. Mexican Sp. tollon (to 'on), the native name.]

\section{$\underline{\text { tuza }} 1787$}

A Mexican pocket-gopher or pouched rat: a rodent, formerly supposed to be a kind of mole.

[a. Sp. tuza, ad. Mexican tuçan or tozan, the native name.] 
Appendix F

Citations for OED Entries

The following citations for individual entries are accurate as of September, 2008.

ahuehuete, $n$. ADDITIONS SERIES 1997

amole SECOND EDITION 1989

atlatl SECOND EDITION 1989

atole SECOND EDITION 1989

avocado SECOND EDITION 1989

axolotl SECOND EDITION 1989

cacao SECOND EDITION 1989

cacomistle SECOND EDITION 1989

camote SECOND EDITION 1989

chayote SECOND EDITION 1989

chia, $n .^{2}$ DRAFT ENTRY Sept. 2007

Chicano, $n$. and $a$. SECOND EDITION 1989

chicle, $n$. SECOND EDITION 1989

chilli, chilly SECOND EDITION 1989

chipotle, $n$. DRAFT ENTRY June 2004

chinampa SECOND EDITION 1989

chocolate SECOND EDITION 1989

cocoa SECOND EDITION 1989

colin SECOND EDITION 1989

conepatl SECOND EDITION 1989

copal SECOND EDITION 1989

copalche, -chi SECOND EDITION 1989

coyote SECOND EDITION 1989

guacamole SECOND EDITION 1989

guayule SECOND EDITION 1989 
hule SECOND EDITION 1989

istle SECOND EDITION 1989

jacal SECOND EDITION 1989

jalap SECOND EDITION 1989

jalapeño ADDITIONS SERIES 1993

iicama, $n$. ADDITIONS SERIES 1997

iicara SECOND EDITION 1989

mariachi, $n$. and $a d j$. DRAFT REVISION Dec. 2000

marijuana, $n$ * DRAFT REVISION June 2008

mazame, $n$. DRAFT REVISION June 2008

Mazatec, $a d j$. and $n$. DRAFT REVISION Mar. 2001

mecate, $n$. DRAFT REVISION June 2001

melt, $n .{ }^{2}$ DRAFT REVISION June 2001

mescal, $n$. DRAFT REVISION June 2008

mesquite, $n$. DRAFT REVISION June 2008

mesteque, $n$. DRAFT REVISION June 2008

metate, $n$. DRAFT REVISION Mar. 2008

Mexican, $n$. and adj. DRAFT REVISION Sept. 2008

milpa, $n$. DRAFT REVISION Mar. 2002

Mixe, $n$. and $a d j$. DRAFT ENTRY June 2008

Mixteca, $n$. and $a d j$. DRAFT ENTRY June 2008

Mixteco, $n$. and $a d j$. DRAFT ENTRY Sept. 2002

mizquitl, $n$. DRAFT REVISION June 2008

molcajete, $n$. DRAFT ENTRY Sept. 2002

mole, $n .^{7}$ DRAFT REVISION Sept. 2002

Montezuma, $n$. DRAFT REVISION Dec. 2007

nagual, $n$. DRAFT ENTRY June 2003

Nahua, $n$. and $a d j$. DRAFT REVISION June 2003 
Nahuatl, $a d j$. and $n$. DRAFT REVISION June 2008

Nahuatlaca, $n$. and adj. DRAFT REVISION Sept. 2008

Nahuatlan, $n$. and adj. DRAFT REVISION Mar. 2008

nopal, $n$. DRAFT REVISION Sept. 2008

Oaxacan, $n$. and $a d j$. DRAFT REVISION June 2008

ocelot, $n$. DRAFT REVISION Mar. 2004

ocote, $n$. DRAFT REVISION Dec. 2007

octli, $n$. DRAFT REVISION Mar. 2004

Olmec, $n$. and $a d j$. DRAFT REVISION June 2008

Olmeca, $n$. DRAFT ENTRY Dec. 2007

ololiuqui, $n$. DRAFT REVISION June 2004

Otomi, $n$. and adj. DRAFT REVISION Mar. 2008

oyamel, $n$. DRAFT ENTRY Dec. 2007

palapa, $n$. DRAFT ENTRY June 2008

pauxi, $n$. DRAFT REVISION June 2008

petaca, $n$. DRAFT ENTRY June 2008

petate, $n$. DRAFT ENTRY Dec. 2005

peyote, $n$. DRAFT REVISION Dec. 2005

pinacate, $n$. DRAFT ENTRY June 2006

pinole, $n$. DRAFT REVISION June 2007

posole, $n$. DRAFT ENTRY June 2008

pulque, $n$. DRAFT REVISION June 2008

pupusa, $n$. DRAFT ENTRY Sept. 2007

quamoclit, $n$. DRAFT REVISION June 2008

quetzal, $n$. DRAFT REVISION June 2008

Quetzalcoatl, $n$. DRAFT REVISION Dec. 2007

sacate, zacate SECOND EDITION 1989 
saguaro, $n$. SECOND EDITION 1989

shack, $n \cdot{ }^{3}$ SECOND EDITION 1989

sotol SECOND EDITION 1989

Subtiaba SECOND EDITION 1989

tacamahac SECOND EDITION 1989

tamal SECOND EDITION 1989

$\underline{\text { tapayaxin }}$ SECOND EDITION 1989

Tecoma SECOND EDITION 1989

$\underline{\text { teguexin }}$ SECOND EDITION 1989

teocalli SECOND EDITION 1989

teonanacatl SECOND EDITION 1989

tepache SECOND EDITION 1989

tequila SECOND EDITION 1989

tilma SECOND EDITION 1989

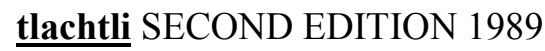

Tlapanec, $n$. (and $a d j$.) SECOND EDITION 1989

toloache SECOND EDITION 1989

Toltec $(n$. and $a$.) SECOND EDITION 1989

Totonac SECOND EDITION 1989

toyon SECOND EDITION 1989

tule SECOND EDITION 1989

tuza SECOND EDITION 1989

Zapotec, $n$. and $a$. SECOND EDITION 1989 


\section{Appendix G \\ Nahuatl Loan Words Identified by Watson (1938)}

Watson (1938) lists many words of Nahuatl origin in American English. I include his complete list here, indicating his definitions and proposed etymologies for words that are not included in the OED, along with the page number reference for each word. Words that are also listed in the OED as having Nahuatl etymologies are marked with an asterisk (*), and the definitions and etymologies for these are not repeated here (refer to Appendices A and B above). Watson's words that are listed in the OED but which are not noted as having Nahuatl etymologies are marked with the crosshatch (\#).

anacahuitap. 111

'a small tree (Cordia boissieri) found on the lower Rio Grande, the wood as well as the leaf and fleshy fruit being used medicinally in throat and chest complaints by Mexican natives of Texas' $<$ Nah. anacahuitl, quahuitl 'tree'

anaqua also: knackaway p.111

'a green-leaved tree of the borage family (Ehretia elliptica)'

cp. anacahuita

amole p.119

'a substance obtained by pounding the roots of the yucca or Spanish bayonet'

$<$ Nah. amolli, $a$ - 'water' + -molli 'a saponaceous vegetable substance'

*atolep. 116

*avocadop.109

*axolotl p.109

ayacahuitap. 111

'a pine tree (Pinus strobiformis) of the Southwest, otherwise called the Mexican white pine'

$<$ Nah. ayacuahuitl or ayauhquauitl. cp. anacahuita

*acaop. 108

* cacomistlep. 118

cacomite p.116

'a species of Tigridia from which a good flour is prepared' (from Bartlett 1859)

$<$ Nah. cacomitl 'a root that has a chestnut-like taste'

*amote p.116

capules p. 115

'a rosaceous shrub or small tree bearing blackish red or deepish yellow edible berries of an agreeable odor'

$<$ Nah. capulin 'the cherry-tree or its fruit'

chacalac p.119

'The Texan guan (Ortalis vetula maccalli)'

$<$ Nah. chacalaca 'imitative term signifying the cackling of a bird'

chacatep.111

'A small bush known to botanists as Krameria canescens or grayi, in various parts of Texas'

$<$ Nah. chacatl

* chia p. 115

chicalote p.111

'The white-flowered thorn-poppy (Argemone platyceras), found in southern California'

$<$ Nah. chicalotl 'a spiny herb' 


\section{* chicle p. 120}

chilacayotealso, chicayote, chilicothe p.116

'Several species of gourds having fruits with and edible pulp (especially eaten as a dessert), found in various southwestern States'

$<$ Nah. tzilacayotli, tzilac 'flat, smooth' + ayotli 'gourd'

chilaquiles p.116

'A vegetable dish seasoned with chilchotes'

$<$ Nah. chilaquilitl, chilli 'chile' + quilitl 'an edible herb'

chilchote p.116

"A Texan word signifying "green or sweet peppers"

$<$ Nah. chilchotl 'green or sweet peppers'

* chile also chili, chilli p.109

chiltapinalso: chiltepin, chilchipines p.112

'Bird-pepper (Capiscum baccatum), pungent red oval berries of this plant were [and still are - JH] prized as a condiment'

$<$ Nah. chilli + tecpin 'flea'

*chocolate p. 109

claco also: tlaco, tlacp.121

"In reference to Mexican money found in Texas. "This word is derived from Mexican Spanish tlaco or claco, denoting 'half', from the fact that the coin has half the value of the quartilla."

$<$ tlaco 'half', see also cacomistle

comal p.120

'A slightly concave utensil of stone or earthenware, or more recently an iron dish, for the purpose of baking tortillas'

$<$ Nah. comalli 'a crude form of earthenware griddle'

* conepatlalso: conepate p.109

*copal p.108

* coyote p. 118

coyotillo p.112

"The beautiful-leaved west Texas shrub Karwinskia humboldtiana, [which] bears blackish edible berries or fleshy drupes, the eating of which is popularly supposed to cause paralysis of the lower extremities, but to be harmless if the small, round seed is rejected. In Mexican folk-lore it is held that the coyote, while fond of the berry, rejects the seed as pernicious: hence the name, formed from coyote... plus the Spanish diminutive -illo."

$<$ Sp. coyote + -illo DIM

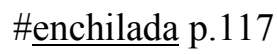

esquitep. 117

'pop-corn sweetened', synonymous with tequesquite

$<$ Nah. izquitl $<$ icequi 'to roast corn or chickpeas on a flat earthenware dish'

\#hoactzin also, hoatzin p.109 
"The remarkable bird Opisthocomus hoazin or O. cristatus, inhabiting tropical America, has been known in English since 1661 as the hoactzin or hoatzin and (from the fetid smell of the male) later as the stinkbird".

$<$ Nah. uatzin [attributed to Webster's 1934]

huajealso: guage p.112

'designating a tree indigenous to and very common in Mexico and certain parts of the south'

$<$ Nah. huaxin 'a tree indigenous to and very common in Mexico and certain parts of the south'

huajillo also: juajillo p.112

cp. huaje, + -illo DIM (Sp.)

huajolote also: guajolote p.119

'A species of wild turkey, Meleagris gallopavo mexicana, as called in some parts of Texas'

$<$ Nah. huexolotl

huisache p.112

'A small tree (Acacia farnesiana) whose fragrant yellow flowers are used in perfumery'

$<$ Nah. huitzachin, huitzli + achi 'a spiny shrub'

*istlealso: ixtle, istle-grass p.114

iztlialso: iztle p. 120

'A cutting implement made of a flake of obsidian'

$<$ Nah. itztli 'a sort of obsidian from which Indians shape arrowheads, knives and other like articles'

*jacal p.119

*jalap p.109

jalapa pp.112-113

'Jathropha macrorhiza, commonly found along the course of the lower Rio Grande.' "Since the rhizome is purgative as well as emetic, the origin of this name may be referred to jalap"

$<$ Nah. xalapa 'the name of several trees whose roots yield a purgative medicine'

cp. jalap

*jicara p. 120

jicote p. 118

'A species of bee (Tallichet says 'a ground bee'), which gives a very painful sting', as known in Texas. "In Mexico jicote is used more generally, being applied not only to various species of bees, but also to hornets or wasps".

$<$ Nah. xicotli 'a species of large honeybee'

jilote p. 117

"An ear of green corn, or "roasting ear"

$<$ Nah. xilotl 'an ear of green corn, a roasting ear'

jocqui p. 118

'A Texas designation for buttermilk'

$<$ Sp. jocoqui $<$ Nah. xococ 'bitter foodstuff made with milk'

*mecate p. 120

* mescal also: mezcal p.118 
*mesquite also: mesquitalp.113

*metate p.121

*Mexico p.109

*milpa p.121

nixtamal p.117

'In Texas, a dish made of whole corn softened in a lime or lye solution'

$<$ Nah. nextamalli, cp. tamal

*nopalalso: nopalera, nopalry p.113

*ocelot p.109

ocotillo p.113

"Jacob's wand, Fouquieria splendens, a spiny tree or shrub which loves to gladden the deserts after the annual rains by putting forth its bright scarlet flowers and its foliage". "Also applied to a species of candlewood related to it.'

$<\underline{\text { ocote }}+\underline{-i l l o}$ DIM, cp. ocote

*peyote p.113

*pinole p.117

quiote p. 116

'Applied to the fruit of certain agaves which after baking are used as foodstuffs in Texas'

$<$ Nah. quiotl or quiotl 'a shoot or sprout, especially of the maguey'

*sacatealso: zacate p.114

sapodillacp. $\underline{\text { sapote }}+$ Sp. $-\underline{\text { illa DIMp } .108}$

\#sapote also: zapote p.113

'The Mexican or black persimmon, Diospyros texana, a small tree which yields a black stain or dye'

$<$ Nah. tzapotl 'applied to various trees of diverse genera and the fruits they bear'

sinsontle p.119

"A Texan designation - "especially current among Mexican natives" - of the mocking bird'

$<$ Nah. centzontlatolli 'four hundred (or a myriad of) voices'

* sotol also: sotole p.118

* tacamahaca also: tacamahac p.108

tamal also: tamale p.117

$<$ Nah. tamalli

tecolote p.119

'The great horned owl, Bubo virginianus subarcticus, as known in Texas (from Spanish tecolote)'

$<$ Nah. tencolotl 'a name said to have reference to the curvature of [an owl's] beak'

*teocalli p.109

tepocatep. 119

'A Texan name for the tadpole' 
$<$ Nah. atepocatl 'a spawn of frogs'

tepopote p.114

"An additional name for the cañatilla, the evergreen shrub Ephedra antisyphilitica; "This small shrub, says Havard, affords a popular remedy among Mexicans and frontiersmen in cases of gonorrhoea and syphilis"

$<$ Nah. tetl 'stone' + popotl 'broom'

tequesquite $\mathrm{p} .117$

'Texan, "signifying according to Tallichet 'a kind of pop-corn', is identical in meaning with esquite... and in form with another Mexican term known to our travelers and others from 1844 as denoting a native carbonate of soda mixed with sulphate and common salt, which effervesces after wet weather and later forms a crust".

$<$ Nah. tequixquitl 'salt-peter', cp. esquite, tesquite

\#tequila $<$ Nah. Tequilan 'the place of the divide'p.118

tesquite $<$ Nah. tequixquitl 'salt-peter', cp. esquite, tequesquitep.121

*tilma p.121

*toloache p.114

*tomato p.109

*tule p. 115

*zopilote p.119 